\title{
Księstwo Mazowieckie u progu inkorporacji. Charakterystyka obszaru około 1526 r. (część południowa)
}

\author{
Marta Piber-Zbieranowska \\ https://orcid.org/0000-0001-8193-1752 \\ Instytut Historii im. Tadeusza Manteuffla Polskiej Akademii Nauk
}

Zarys treści: Artykuł jest pierwszą z dwóch części przeglądu dziesięciu ziem Księstwa Mazowieckiego i tworzących je powiatów w przededniu włączenia ich do Królestwa Polskiego we wrześniu 1526 r. Przedstawiono w nim cztery południowe ziemie: czerską i warszawską, stanowiące trzon polityczny władztwa ostatnich Piastów, oraz wyodrębnione z nich w ciaggu XV w. - liwską i nurską. W sumie obszar ten obejmował dziesięć powiatów. Wszystkie ziemie księstwa mazowieckiego scharakteryzowano według jednolitego schematu, w obowiązującym ówcześnie układzie starszeństwa. Poszczególne ziemie zaprezentowano pod kątem podziałów administracyjnych (państwowych i kościelnych), procesów osadniczych i stanu sieci miejskiej, typów i rozmieszczenia własności ziemskiej oraz pozycji danej ziemi w strukturach politycznych księstwa, wyrażającej się m.in. funkcjonowaniem pełnej bądź niepełnej hierarchii urzędów oraz udziale szlachty danej ziemi w sprawowaniu władzy. Starano się pokazać zróżnicowanie stopnia zagospodarowania ziem mazowieckich i wskazać jego genezę.

Słowa kluczowe: Księstwo Mazowieckie, rozwój osadnictwa, południowe Mazowsze, podziały administracyjne, sieć miejska, hierarchia urzędnicza, struktura własności, szlachta bezkmieca

Na geograficzno-polityczny kształt Księstwa Mazowieckiego ${ }^{1} \mathrm{w}_{\text {prezentowanym }}$ momencie dziejowym wpływ miały wydarzenia zapoczątkowane w lutym 1495 r. śmiercią bezżennego księcia Janusza II. Jego starszy brat, książę czerski

\footnotetext{
${ }^{1}$ Mapa Księstwa Mazowieckiego w kształcie sprzed 1526 r., opublikowana zostanie jako dodatek do drugiej części niniejszego artykułu, dotyczącej części północnej.
}

Abstract: This article is the first of a two-part review of ten lands of the Duchy of Mazovia and the counties that constituted them on the eve of their incorporation into the Kingdom of Poland in September 1526. It presents four southern lands: of Czersk, Warsaw, Liw, and Nur. The first two made the political core of the last Piasts' rule, while the latter two were separated from those two in the fifteenth century. In total, this area encompassed ten counties. All the lands of the Duchy of Mazovia are characterised according to a uniform scheme, in the then binding seniority system. Particular lands were presented in terms of administrative divisions (state and Church ones), settlement processes, and the state of the urban network, the types and distribution of land ownership, and the position of a given land in the political structures of the duchy, expressed among other things by the functioning of a complete or incomplete hierarchy of offices, and the participation of the nobility of a given land in the exercise of power. Attempts have been made to show the diversity in the degree of development of Mazovian lands and to indicate its genesis.

Keywords: Duchy of Mazovia, settlement development, southern Mazovia, administrative divisions, urban network, hierarchy of offices, ownership structure, landless nobility

Konrad III Rudy, próbował wówczas, wbrew zamysłom króla polskiego, przejać pozostałą po Januszu schedę. Eskalację konfliktu i działania zbrojne obu stron udało się jednak powstrzymać i doprowadzono do ugody. Na podstawie wyroków sądowych z 1468 r., które odsądziły Konrada III od posiadania ziem księstwa zachodniomazowieckiego, król Jan Olbracht 
inkorporował do Korony część władztwa zmarłego księcia, tj. ziemie płocką, płońską i zawkrzeńską (utworzono z nich wówczas województwo płockie) oraz ziemię wiską. 20 kwietnia 1496 r. na sejmie w Piotrkowie król polski nadał Konradowi III w dziedziczne lenno całe księstwo czerskie oraz w dożywocie ziemie: warszawską, wyszogrodzką, zakroczymską, ciechanowską i łomżyńską. 13 stycznia 1497 r. w Lublinie książę złożył hołd lenny królowi oraz poręczył, że zrobią to także urzędnicy i szlachta nadanych mu dożywotnio ziem² ${ }^{2}$ W myśl tych porozumień po śmierci Konrada III, która miała miejsce 28 października 1503 r., król Aleksander Jagiellończyk podjął działania zmierzające do włączenia księstwa do Korony. Wobec sprzeciwu księżnej Anny Radziwiłłówny, sprawującej regencję $\mathrm{w}$ imieniu małoletnich synów Konrada III, oraz możnowładztwa i szlachty mazowieckiej, po półrocznych pertraktacjach udało się zawrzeć korzystny dla Mazowsza układ. 14 marca 1504 r. król polski nadał Stanisławowi i Januszowi Konradowicom w dziedziczne lenno ziemie: warszawską, wyszogrodzką, zakroczymską, ciechanowską i łomżyńską, a szczegółowe postanowienia ugody objęły również ziemię czerską posiadaną przez nich na zasadzie dziedzictwa po ojcu, Konradzie III ${ }^{3}$. W czerwcu 1511 r. księżna Anna wraz z synami przejęła formalnie rządy w ziemi wiskiej, pozostającej od 1495 r. poza granicami księstwa ${ }^{4}$. W marcu 1526 r., w chwili śmierci ostatniego

\footnotetext{
2 Iura Masoviae terrestria [dalej: IMT], t. 2, oprac. J. Sawicki, Warszawa 1973 , nr 121-123, 153-155, 158; P. Węcowski, Mazowsze w Koronie. Propaganda i legitymizacja władzy Kazimierza Jagiellończyka na Mazowszu, Kraków 2004, s. 65-67, 84-96; J. Grabowski, Dynastia Piastów mazowieckich. Studia nad dziejami politycznymi Mazowsza, intytulacją i genealogią książąt, Kraków 2012, s. 190-192. Nadanie w lenno ziemi czerskiej (obejmującej też ziemię liwską) wynikało z uznania przez króla praw dziedzicznych Konrada III do całego obszaru, który przypadł mu w podziale ojcowizny z braćmi w 1471 r. (tamże, Aneks I, nr 18)

${ }_{3}^{3}$ IMT, t. 2, nr 171, 172; M. Piber-Zbieranowska, „Księżna mazowiecka Anna Radziwittówna i jej regencja na Mazowszu (1503-1518)”, Warszawa 2019, mps pracy doktorskiej w Bibliotece IH PAN w Warszawie, s. 32-67.

${ }^{4}$ Odbyło się to za zgodą króla, po wykupieniu jej przez książą z rąk prywatnych, J. Grabowski, Dynastia, s. 199
}

Piasta mazowieckiego - Janusza III, teren Księstwa Mazowieckiego stanowiło zatem dziesięć ziem, które łącznie zajmowały $23016 \mathrm{~km}^{2}$ powierzchni ${ }^{5}$. Po inkorporacji do Korony we wrześniu 1526 r. utworzono z nich województwo mazowieckie, funkcjonujące $\mathrm{w}$ niezmienionych granicach aż do drugiego rozbioru Polski w 1793 r. $^{6}$

Istniejący za ostatnich Piastów mazowieckich system podziałów terytorialnych Księstwa Mazowieckiego związany był z sądownictwem. Funkcjonujący wówczas na Mazowszu ustrój sądowy, zorganizowany na podstawie terytorialnej, rozwinął się stopniowo i ustalił w drugiej połowie XIV w., wprowadzając obszary niższej instancji - powiaty i wyższej - ziemie ${ }^{7}$. Uformowany nieco wcześniej, tj. w ciągu XIV w., system podziałów administracji książęcej, który opierał się na dzielnicach (districtus), powstałych i działających w ramach podziałów politycznych ${ }^{8}$, w początkach XVI w. w zasadzie nie był wykorzystywany. Do celów administracji państwowej stosowano już powszechnie podziały sądowe. Przypuszczalnie wpływ na to miała również i administracja koronna, obejmująca swym działaniem ziemie wchodzące niegdyś w skład księstwa zachodniomazowieckiego, w której termin districtus oznaczał jedynie powiat sądowy,

\footnotetext{
${ }^{5}$ Obliczenia powierzchni na podstawie: A. Dunin-Wąsowiczowa, Podziały administracyjne, w: Mazowsze w drugiej połowie XVI wieku, cz. 2: Komentarz i indeksy, red. W. Pałucki, oprac. A. Dunin-Wąsowiczowa i in., Warszawa 1973 (Atlas historyczny Polski. Mapy szczegótowe XVI wieku [dalej: AHPMaz.], 7), s. 59, Aneks I: Powierzchnia powiatów i ziem Mazowsza.

${ }^{6}$ Na mocy postanowień drugiego rozbioru Prusy zajęły gros województwa płockiego i rawskiego oraz zachodni skrawek województwa mazowieckiego z Wyszogrodem. Część Mazowsza, która pozostała przy Polsce, została podzielona na trzy województwa: ciechanowskie (ziemie ciechanowska, różańska, zakroczymska), mazowieckie (ziemie tomżyńska, nurska, wiska) i warszawskie (ziemie czerska, liwska, warszawska), J. Szczepański,Ziemie Mazowsza w okresie insurekcji 1794 roku, w: Dzieje Mazowsza, t. 2: Lata 1527-1794, red. J. Tyszkiewicz, Pultusk 2015, s. 604.

${ }^{7}$ A. Wolff, Studia nad urzędnikami mazowieckimi 1370-1526, Wrocław-Warszawa-Kraków 1962, s. 12-13; tenże,Ziemia fomżyńska w średniowieczu, Łomża 1988, s. 12-14.

${ }^{8}$ Dzielnice dzielity się na jednostki niższego rzędu skoncentrowane wokół gtównych grodów - najczęściej dawnych kasztelanii, A. Wolff, Studia, s. 11; H. Samsonowicz, A. Supruniuk, Dzieje polityczne (połowa XIV - początek XVI w.), w: Dzieje Mazowsza, t. 1, red. H. Samsonowicz, Puttusk 2006, s. $319-320$.
} 
a potem również i skarbowy. Wzajemne powiązania rodzinno-majątkowe Mazowszan z ziem inkorporowanych i tych pozostałych w księstwie, których nie zniosły przecież zmiany granic politycznych, mogły wymuszać dążenie do ujednolicenia stosowanej terminologii ${ }^{9}$.

Niniejszy artykuł stanowi pierwszą z dwóch części przeglądu dziesięciu ziem Księstwa Mazowieckiego i tworzących je powiatów w przededniu włączenia ich do Królestwa Polskiego w 1526 r. Scharakteryzowano tu cztery ziemie - czerską i warszawską oraz wyodrębnione $\mathrm{z}$ nich w ciągu XV w. - liwską i nurską, obejmujące $\mathrm{w}$ sumie dziesięć powiatów. Ziemie czerska i warszawska stanowiły trzon polityczny władztwa księcia Konrada III i jego synów, stąd też od nich zaczęto prezentację. Wszystkie ziemie księstwa mazowieckiego przedstawiono według tego samego schematu, umożliwiającego ewentualne późniejsze ich porównanie. Poszczególne ziemie zaprezentowano pod kątem podziałów administracyjnych (państwowych i kościelnych), procesów osadniczych i stanu sieci miejskiej, własności ziemskiej oraz pozycji danej ziemi w strukturach politycznych księstwa. Na sposób opracowania tych zagadnień (zwłaszcza stosunków własnościowych) i ich prezentacji, niekiedy odmienny dla poszczególnych ziem, zasadniczy wpływ miał stan zachowania źródeł natury skarbowej (głównie poboru łanowego), które dla południowej części księstwa pochodzą dopiero z czwartej dekady XVI w. ${ }^{10}$

Starano się pokazać zróżnicowanie stopnia zagospodarowania ziem mazowieckich i wskazać jego genezę. Różnice w rozwoju i charakterze osadnictwa spowodowane były w dużej mierze

\footnotetext{
${ }_{9}^{9}$ Por. J. Grabowski, Dzieje Makowa w czasach Piastów Mazowieckich, w: Dzieje Makowa Mazowieckiego, t. 1, red. J. Szczepański, Maków Mazowiecki-Puttusk 2020, s. 25.

${ }^{10}$ I. Gieysztorowa, Mazowieckie akta skarbowe w XV-XVII w., próba odtworzenia uktadu, w: Księga Pamiątkowa 150-lecia Archiwum Gtównego Akt Dawnych w Warszawie, Warszawa 1958, s. 209-217.
}

warunkami naturalnymi - rozległe tereny leśne, często także podmokłe, hamowały procesy kolonizacyjne. Odmienności te wynikały jednak przede wszystkim z czynników geopolitycznych i historycznych. Tereny wschodnie i północno-wschodnie księstwa praktycznie do schyłku XIV w. nękane były wyniszczającym najazdami Prusów, Jaćwingów i Litwinów i dopiero po ich ustaniu zaczęły być systematycznie zasiedlane, głównie drogą nadań książęcych dla rycerstwa ${ }^{11}$. Zagrożenie wojenne powodowało ponadto, że obszary te nie były w zasadzie przedmiotem darowizn dla instytucji kościelnych. Czas i poziom zagospodarowania poszczególnych ziem wpłynęły na ich znaczenie polityczne, przejawiające się w udziale pochodzącej z nich szlachty we władzy i zarządzie księstwem oraz w ścieżkach awansów urzędniczych. Powiązana z rolą polityczną pozycja danej ziemi w hierarchii terytorialnej po inkorporacji przeniesiona została w struktury Królestwa Polskiego. Przykładowo kasztelan czerski jako jedyny spośród kasztelanów byłego księstwa mazowieckiego wszedł w senacie do grona kasztelanów większych (tzw. krzesłowych). Gdy w 1552 r. król Zygmunt August próbował ograniczyć liczebność reprezentacji Mazowsza na sejm generalny, w wydanym uniwersale królewskim w wykazie ziem uprawnionych do wysłania swych posłów pominięto ziemie łomżyńską, nurską i różańską ${ }^{12}$. Wybór tych właśnie ziem nie był przypadkowy i wynikał z pewnością z ich niskiego miejsca w starszeństwie ziem czasów książęcych, związanego z brakiem urzędu kasztelana. Struktura społeczno-ekonomiczna ziem Księstwa Mazowieckiego, charakteryzująca się niespotykaną w reszcie Rzeczypospolitej

\footnotetext{
${ }^{11}$ S. Russocki, Nadania ziemi „ad servitia communia” a obowiązek stużby wojskowej na Mazowszu w XV wieku, w: Miscellanea iuridica złożone w darze Karolowi Koranyiemu w czterdziestolecie pracy naukowej, red. K. Bukowska, Warszawa 1961, s. 117-119; tenże, Formy władania ziemią w prawie ziemskim Mazowsza. Koniec XIV - połowa XVI wieku, Warszawa 1962, s. 66-67.

${ }^{12}$ J. Choińska-Mika, Mazowiecki parlamentaryzm XVI-XVII w., w: Dzieje Mazowsza, t. 2, s. 120.
} 
przewagą szlachty, szczególnie warstwy średnio- i drobnoszlacheckiej (ze znaczącym odsetkiem bezkmiecej szlachty zagrodowej) miała po 1526 r. istotny wpływ na kierunek rozwoju demokracji szlacheckiej $^{13}$.

Za rządów Konrada III i jego synów najwyżej w starszeństwie hierarchicznym ziem Księstwa Mazowieckiego znajdowała się ziemia czerska. Po niej następowały inne ziemie mające kasztelanie - wiska, warszawska, wyszogrodzka, zakroczymska i ciechanowska. Niższe miejsca zajmowały ziemie: łomżyńska, liwska, nurska i makowsko-różańska ${ }^{14}$. W omawianym czasie ziemia czerska podzielona była na trzy powiaty: czerski, grójecki (zwany też grodzieckim) i warecki ${ }^{15}$. Pod względem przynależności do administracji kościelnej zdecydowana większość ziemi czerskiej należała do archidiakonatu warszawskiego diecezji poznańskiej, natomiast w najbardziej wysuniętej na południe części powiatu wareckiego, położonej między Pilicą a Radomką, stykały się granice archidiakonatu kurzelowskiego archidiecezji gnieźnieńskiej (należały tu parafie: Wyśmierzyce, Jasionna i Stromiec) oraz archidiakonatu radomskiego diecezji krakowskiej (par. Głowaczów) ${ }^{16}$. Swym zasięgiem ziemia czerska obejmowała rozległe

${ }^{13}$ W. Pałucki, Przynależność własnościowa osad, w: AHPMaz., cz. 2, s. 97-98; J. Dzięgielewski, Mazowsze w czasach ostatnich Jagiellonów, w: Mazowsze w procesach integracyjnych i dezintegracyjnych w Rzeczypospolitej XVI-XVII wieku. Studia i szkice, red. tenże, Warszawa 2010, s. 51-53.

${ }^{14}$ S. Russocki, K. Pacuski, Ustrój polityczny i prawo, w: Dzieje Mazowsza, t. 1 s. 409. Zaznaczyć trzeba, że ustalenie się takiego porządku było trwającym kilkadziesiąt lat procesem. Starszeństwem ziem książęcego Mazowsza zajmował się ogólnie A. Wolff, Studia, s. 58-61, a ostatnio omówił je szerzej J. Grabowski, Dynastia, s. 391-401. Zagadnienie to jednak nadal wymaga bardziej pogtębionych badań, por. A. Gąsiorowski, Starszeństwo urzędów w Polsce późnośredniowiecznej, „Roczniki Historyczne”, 35, 1969, s. 33-56.

${ }^{15}$ Powiat garwoliński - czwarty powiat ziemi czerskiej (wyłącznie sądowy) wydzielony został dopiero w 1539 r., więcej na temat zob.: M. Piber-Zbieranowska, Uwagi nad początkami powiatu garwolińskiego w ziem czerskiej, w: Fines testis temporum. Studia ofiarowane Profesor Elżbiecie Kowalczyk-Heyman w pięćdziesięciolecie pracy naukowej, red. M. Dzik, G. Śnieżko, Rzeszów 2017, s. 97-106.

${ }^{16}$ AHPMaz, cz. 1: Mapy, plany, mapa nr 1: Mazowsze $w$ drugiej połowie XVIw. (mapa gtówna), część południowa z mapką: Podziaty administracyjne Mazowsza; T. Jurek, Diecezja poznańska w późnym średniowieczu (mapa), w: tenże, Biskupstwo poznańskie w wiekach średnich, Poznań 2018, s. 545 tereny położone po obu stronach Wisły, a jej powierzchnia wynosiła w sumie ponad 4 tys. $\mathrm{km}^{2}$, co stawiało ją wśród ziem mazowieckich na drugim miejscu pod względem zajmowanego obszaru, tuż po ziemi łomżyńskiej ${ }^{17}$. Ziemia czerska zaliczana była do tzw. Starego Mazowsza ${ }^{18}$, w jej części lewobrzeżnej koncentrowało się najstarsze osadnictwo na wschodnim Mazowszu, datowane w sposób ciagły od XII w. ${ }^{19}$ Stąd rozchodziły się późniejsze (od początków XV w.) migracje w kierunku północnym i północno-wschodnim, przede wszystkim na tereny późniejszej ziemi liwskiej ${ }^{20}$. Natomiast tereny prawobrzeżne, zawiślańskie jeszcze na początku XVI w. w niemałej części gęsto porośnięte były lasami (Puszcze Starogrodzka, Osiecka i Dębska ${ }^{21}$, a ożywiona akcja osadnicza, widoczna także w prawdziwej eksplozji prywatnych lokacji miejskich, ruszyła tu dopiero w trzecim i czwartym dziesięcioleciu XVI w. ${ }^{22}$ Ziemia czerska była też najbardziej zurbanizowana spośród ziem władztwa Konradowiców, miała największą w księstwie liczbę miast - w 1526 r. było tu ich dwanaście ${ }^{23}$. Analizując strukturę własności ziemskiej, stwierdzić należy, że zlokalizowane tu były największe skupiska własności książęcej na Mazowszu, które koncentrowały się wokół miast: Czerska,

\footnotetext{
${ }^{17}$ Zob. przyp. 5.

${ }^{18}$ Oprócz czerskiej zaliczano niego także ziemie: warszawską, zakroczymską i wyszogrodzką.

${ }^{19}$ S. Gawlas, Osadnictwo ziemi czerskiej w średniowieczu XII-XV w., w: Dzieje Warki 1321-1971. Studia i materiaty, praca zbiorowa, red. B. Dymek i in., Warszawa 1975, s. 29-33.

${ }^{20}$ M. Wilska, Mazowieckie środowisko dworskie Janusza Starszego. Studium społeczne, Warszawa 2012, s. 19.

${ }^{21}$ Starsze osadnictwo skupiało się w dolinie Wisły i nad pozostałymi ciekami wodnymi, S. Gawlas, Osadnictwo, s. 36.0 specyfice topograficznej tego obszaru świadczyć może jego nazwa - Polesie, znana z szesnastowiecznych źródeł, poświadczająca późny charakter tutejszego osadnictwa, M. Piber-Zbieranowska, Uwagi nad początkami powiatu garwolińskiego, s. 97.

${ }^{22}$ M. Piber-Zbieranowska, referat pt. „Miasta prywatne na Mazowszu (do końca XVI w.)" wygtoszony na konferencii „Miasta prywatne w sieci miejskiej Królestwa Polskiego i Rzeczypospolitej Obojga Narodów", która odbyła się 23-24 kwietnia 2015 r. w Zamościu.

${ }^{23}$ Sześć miast książęcych (zob. dalej), cztery miasta szlacheckie (Magnuszewo, Mińsk, Głowaczów i Sienica), dwa kościelne (zob. dalej). W drugiej połowie XVI w. liczba miast w ziemi czerskiej wynosiła już 25, I. Gieysztorowa, Charakter i wielkość osad, w: AHPMaz., t. 2, s. 85
} 
Grójca, Warki, Goszczyna, Garwolina i Latowicza oraz dworu myśliwskiego w Osiec$\mathrm{ku}^{24}$. Własność kościelna była natomiast stosunkowo niewielka i rozproszona. Większy kompleks tworzyły dobra należące do opactwa benedyktynów w Płocku (miasta Przybyszew i Wyśmierzyce z czterema wsiami i dwie wsie nad rz. Jeziorka). Klucz dóbr arcybiskupów gnieźnieńskich obejmował pięć wsi na północ od ujścia Pilicy do Wisły. Własność biskupów poznańskich stanowiło w sumie dziewiętnaście wsi, z których większość położona była południowym wschodzie ziemi czerskiej, nad rzeką Świder (od lokacji w 1547 r. ośrodkiem tych dóbr stało się miasto Stoczek). W posiadaniu szpitala św. Ducha przy kościele św. Marcina w Warszawie było $\mathrm{w}$ tym czasie dwanaście wsi (w par. Kiczki). Pięć wsi należało do kapituły kolegiackiej w Warszawie, a jedna do probostwa w Czersku ${ }^{25}$.

W strukturze dóbr należących do szlachty dominowała własność średnia ${ }^{26}$.

\footnotetext{
${ }^{24}$ Według szacunków Jerzego Senkowskiego w 1526 r. w ziemi czerskiej własnością książęcą było aż 81 wsi, co stanowiło niemal 40 proc. wszystkich ówczesnych dóbr książęcych na Mazowszu. Skoncentrowane one były zwłaszcza w zawiślańskiej części ziemi, J. Senkowski, Skarbowość Mazowsza od końca XV wieku do 1526 roku, Warszawa 1965, s. 20. Zarząd dóbr książęcych podzielony był między starostwo grodowe w Czersku i trzy niegrodowe w Garwolinie, Goszczynie (z ośrodkiem w Bądkowie) i Osiecku.

${ }^{25}$ Szczegółowe wyliczenia wsi znajdują się w Aneksie; J. Warężak, Rozwój uposażenia arcybiskupstwa gnieźnieńskiego w średniowieczu, Lwów 1929, s. 150; J. Karwasińska, Szpital Świętego Ducha w Warszawie. Dzieje fundacji Anny Bolesławowej Księżny Mazowieckiej początkowe (1444-1544), w: taż, Wybór pism. Kujawy i Mazowsze, Warszawa 1997, s. 239-247; A.M. Nowik, Dzieje Cegłowa do 1795 roku, w: Na cegle pisane. Historia miasteczka Cegtów, red. M. Śluzek, Cegtów 2021, s. 8-20; S. Gawlas, Osadnictwo, s. 37. Zob. też W. Pałucki, Przynależność własnościowa osad, s. 88-102; Kartoteka Stownika historyczno-geograficznego Mazowsza w średniowieczu, przechowywana w IH PAN w Warszawie [dalej: Kartoteka Wolffa], pow. czerski, odpowiednie hasła, (https://rcin.org.pl/dlibra/publication/8355\#structure, dostęp: 12 kwietnia 2021).

${ }^{26}$ Przyjmuję tu podział na trzy grupy własnościowe zaproponowany przez Stawomira Gawlasa (Osadnictwo, s. 38), tj. własność: wielowioskowa (skupione w jednym ręku więcej niż dwie wsie), cząstkowa (pięciu i powyżej właścicieli na jedną miejscowość), średnia (pozostałe osady). Według ustaleń tego badacza średnia własność na początku XV w. obejmowała 55 proc. dóbr należących do szlachty (tamże, s. 40). Porównując to z rejestrami poborowymi, zachowanymi dla ziemi czerskiej w sposób rejestrujący opodatkowanych właścicieli niestety dopiero od $1563 \mathrm{r}$. (Archiwum Główne Akt Dawnych [dalej: AGAD], Archiwum Skarbu Koronnego [dalej: ASK] I 46, k. 119-168v), można stwierdzić, że proporcje te nie uległy znaczącej zmianie (mniej 0 ok. 6,5 proc.). Struktura własności szlacheckiej w ziemi czerskiej w omawianym momencie dziejowym, zwłaszcza własność wielowioskowa
}

Stosunkowo nieduży był natomiast w ziemi czerskiej odsetek szlachty cząstkowej i bezkmiecej (zagrodowej) - w jej rękach znajdowało się w omawianym czasie szacunkowo około 13 proc. osad szlacheckich. Największe skupiska szlachty zagrodowej źródła notują w powiecie grójeckim - należało tu do niej około 25 proc. dóbr szlacheckich (przede wszystkim w parafiach Jasieniec, Worowo i Lewiczyn), mniejsze w wareckim - 18 proc. (głównie w par. Wrociszewo). W powiecie czerskim zaś w rękach szlachty zagrodowej znajdowało się tylko ok. 5 proc. osad własności szlacheckiej, a koncentrowały się one głównie $\mathrm{w}$ pasie nadrzecznym na wschód od linii Wisły (w parafiach - Radwankowo i Karczew) ${ }^{27}$.

Ziemia czerska posiadała pełną hierarchię urzędniczą, która uformowała się w XIII-XIV w. ${ }^{28}$ Kolejnymi urzędnikami

wykazująca dużą nietrwałość i pojawiająca się w źródłach z reguły w chwili rozpadu (podział majątku, sprzedaż), wymaga dalszych pogłębionych studiów, uwzględniających rozdawnictwo dóbr prowadzone przez ostatnich książąt mazowieckich Janusza III i jego siostrę Annę w latach 1525-1529 (por. o tym W. Pałucki, Przynależność własnościowa osad, s. 92). Wstęp do tego rodzaju badań, umożliwiający ich przeprowadzenie dla dłuższych sekwencji czasowych (od pierwszej wzmianki do końca XVI w.), stanowią prace nad „Stownikiem historyczno-geograficznym ziemi czerskiej w średniowieczu” prowadzone obecnie w IH PAN w Warszawie.

${ }^{27}$ Podstawą tych jedynie przybliżonych obliczeń był rejestr poboru łanowego z ziemi czerskiej z 1510 r. zachowany tylko dla osad znajdujących się w posiadaniu szachty bezkmiecej (AGAD, ASK I 46, k. 1-6) oraz materiał zgromadzony w Kartotece Wolffa. W pow. czerskim wspomniany rejestr notuje 15 wsi szlachty bezkmiecej w par.: Góra -2 wsie, Sobikowo - 3 , Radwankowo - 6, Karczew - 2, Garwolin - 2); w pow. grójeckim 40 wsi (w par. Worowo -8, Prażmowo - 1, Grójec-1, Błędów - 2, Jeziorka -2, Jasieniec - 8, Łęczeszyce - 1, Lewiczyn - 9, Przybyszewo - 3, Goszczyn - 4, Promna - 1); w pow. wareckim 18 wsi (w par. Warka -2 wsie, Wrociszewo -7 , Magnuszewo -3 , Stromiec - 3, Btotnica - 3).

${ }^{28}$ A. Wolff, Studia, S. 59, „Tablica urzędów”; ,Spis urzędników ziemskich mazowieckich XIII-XV wieku", oprac. K. Pacuski, mps w Zakładzie Stownika Historyczno-Geograficznego Ziem Polskich w Średniowieczu Instytutu Historii PAN w Poznaniu [dalej: Pacuski, Spis]. Na temat formowania się elity władzy w tym okresie oraz przemianach zachodzących w jej strukturze zob.: K. Pacuski, Możnowładztwo i rycerstwo ziemi gostynińskiej w XIV i XV wieku. Studium z dziejów osadnictwa i elity władzy na Mazowszu średniowiecznym, Warszawa 2009 (ustalenia ogólne dla całego księstwa); tenże, O rodzie Radwanów-Wierzbowów na Mazowszu średniowiecznym. Potomkowie Gotarda kasztelana wiskiego, w: Stużew i jego kościót, red. A. Sottan-Lipska, Warszawa 2013, s. 35-67; tenże, Otoczenie księcia warszawskiego w kwietniu 1313 r., w: Ecclesia - regnum - fontes. Studia z dziejów średniowiecza. Prace ofiarowane Profesor Marii Koczerskiej, red. S. Gawlas i in., Warszawa 2014, s. 206-216; tenże, Wspótpracownicy książąt mazowieckich w ziemi warszawskiej w XIV wieku, w: Początki Warszawy. Spojrzenie po 700 latach, red. H. Rutkowski, Warszawa 2015, s. 53-72. 
po kasztelanie według starszeństwa byli: cześnik, sędzia, chorąży, podkomorzy, stolnik, skarbnik, podsędek, wojski, podczaszy i podstoli ${ }^{29}$. Sondażowe badania Henryka Samsonowicza i Anny Supruniuk wykazały, że urzędnicy z najbliższego otoczenia księcia Konrada III, a potem jego synów Stanisława i Janusza III, pochodzili w przeważającej większości z ziem stołecznych, tj. właśnie czerskiej i warszawskiej ${ }^{30}$. Przypatrując się osobom z najbliższego otoczenia księżnej regentki Anny Radziwiłłówny możemy zauważyć, że na 23 osoby, które w czasie jej piętnastoletnich rządów (1503-1518) sprawowały najwyższe urzędy w księstwie - ziemskie (wojewoda i kasztelanowie) oraz dworskie (kanclerz, podkanclerzy, marszałek dworu, ochmistrz i podskarbi), z ziem czerskiej i warszawskiej pochodziła ponad połowa, tj. dwanaście osób ${ }^{31}$.

Ziemia warszawska, do momentu ponownego przyłączenia do księstwa ziemi wiskiej w 1511 r., zajmowała drugie miejsce w hierarchii ziem księstwa. Swym zasięgiem obejmowała tereny położone po obu stronach Wisły o całkowitym obszarze $2890 \mathrm{~km}^{2}$, dzieląc się na trzy powiaty: warszawski, błoński i tarczyński ${ }^{32}$. W ramach administracji kościelnej jej obszar podzielony był między archidiakonat warszawski diecezji poznańskiej, któremu podlegała cała część lewobrzeżna Wisły i niewielki południowy fragment prawobrzeża (zamykający się w trzech parafiach: Zerzeń, Wiązowna i Długa Kościelna), a archidiakonat

\footnotetext{
${ }^{29} 0$ mazowieckiej hierarchii urzędniczej, zob.: A. Wolff, Studia, s. 57. Po stoniku whierarchii urzędów ziemskich stał łowczy. Urząd towczego czerskiego zanikł na początku XIV w. Według badań Kazimierza Pacuskiego jego kontynuacja był towczy warszawski, a urząd ten funkcjonował do 1447 r. (Pacuski, Spis). 0 zadaniach towczego, zob. S. Russocki, K. Pacuski, Ustrój polityczny, s. 410; K. Pacuski, Możnowładztwo i rycerstwo, s. 417-418.

${ }^{30}$ H. Samsonowicz, A. Supruniuk, Dzieje polityczne, s. 322, Tabela 1: Pochodzenie terytorialne urzędników dworskich Mazowsza czerskiego. Badania te objęły końcowe lata panowania Konrada III, ti. 1495-1503 oraz rządy jego synów, tj. lata 1518-1526. W tabeli jest luka dla lat 1503-1518, nie uwzględnia ona rządów regencyjnych Anny Radziwittówny w tym okresie (zob. dalej).

${ }^{31}$ M. Piber-Zbieranowska, Księżna mazowiecka, s. 303-410.

${ }^{32}$ Pod względem powierzchni powiat warszawski był dominujący; jego powierzchnia wynosita ponad 2 tys. $\mathrm{km}^{2}$.
}

pułtuski diecezji płockiej, w którego granicach znajdowała się pozostała, północna część prawobrzeżna ${ }^{33}$. Tereny lewobrzeżne położone wokół Warszawy i na południe od niej również należały do najstarszego osadnictwa księstwa wschodnio-mazowieckiego, skąd rozchodziło się ono przede wszystkim na tereny Pobuża i dalej w kierunku północno-wschodnim. $\mathrm{Di}$ strictus warszawski, w znaczeniu jednostki wyższego rzędu odpowiadającej dzielnicy, obejmował początkowo swym zasięgiem również i tereny późniejszych ziem nurskiej (Kamieniec, Nur i Ostrowia) i łomżyńskiej (Łomża i Nowogród), które wyodrębnily się stopniowo w ciągu XV w. ${ }^{34}$ Prawobrzeżna część ziemi warszawskiej, porośnięta gęsto lasami osadzonymi na terenach podmokłych, jeszcze w połowie XVI w. była słabo zaludniona. Na osiem miast istniejących $\mathrm{w}$ omawianym czasie w ziemi warszawskiej, sześć znajdowało się na lewym brzegu Wisły ${ }^{35}$. Ta niewielka, jak by się wydawało, liczba miast na stosunki mazowieckie była jednak dość znacząca, stawiała bowiem ziemię warszawską na jednym z czołowych miejsc pośród ziem księstwa pod względem stopnia urbanizacji. Przypatrując się stosunkom własnościowym, trzeba wspomnieć o skupiskach własności książęcej związanych ze starostwami błońskim i warszawskim (z miastem Piaseczno) oraz kompleksem dóbr na wschodzie ziemi, na pograniczu z ziemiami liwską i czerską (z ośrodkiem w Stanisławowie). U schyłku niezależności politycznej Mazowsza w ziemi warszawskiej w rękach

\footnotetext{
${ }^{33}$ Zob. wyżej, przyp. 16

${ }^{34}$ A. Wolff, Ziemia fomżyńska, s. 15-17; K. Pacuski, Warszawa - districtus, w: Stownik historyczno-geograficzny ziemi warszawskiej w średniowieczu [dalej: SHGWarsz.], oprac. A. Wolff, K. Pacuski, przyg. do druku M. Piber-Zbieranowska, A. Salina, red. T. Jurek, Warszawa 2013, s. 297; tenże, Wschodnia granica Mazowsza w średniowieczu w świetle danych historycznych (X-XV w.), w: Początki chrześcijaństwa na pograniczu mazowiecko-ruskim w świetle wyników badań wybranych cmentarzysk, red. A. Buko, Warszawa 2019, s. 25

${ }^{35}$ Były to: Stara i Nowa Warszawa, Błonie, Tarczyn, Piaseczno, Nadarzyn, położone w prawobrzeżnej części były Radzymin i Stanisławów. Do końca XVI w. miały miejsce dwie kolejne lokacje, obie prywatne (1538 r. Okuniew; ok. 1545 Nowy Dwór), SHGWarsz., s. 180-181, 187.
} 
książęcych znajdowało się pięć miast i 27 wsi, co stawiało ją pod tym względem na drugim miejscu po ziemi czerskiej ${ }^{36}$.

Własność kościelna w ziemi warszawskiej obejmowała w sumie jedno miasto i 53 całe wsie. Największe posiadłości miało tu opactwo kanoników regularnych w Czerwińsku - 21 wsi (głównie w par. Borzęcin, Wieliszew i Łomna) ${ }^{37}$. Rozległe dobra znajdowały się w posiadaniu kapituty kolegiackiej w Warszawie - jedno miasto i szesnaście wsi, z czego cztery stanowiły majątek wspólny, reszta zaś uposażenie poszczególnych prałatur i kanonii (zob. Aneks) ${ }^{38}$. Do kościoła płockiego należały: cztery wsie biskupa w widłach Narwi i Wisły, cztery - kapituły katedralnej w kluczu Kamion i jedna - dziekana. Dobra biskupów poznańskich stanowiło sześć wsi klucza żbikowskiego. Ponadto uposażeniem kościoła św. Jakuba w Rokitnie była wieś Chroślin, szpitala św. Ducha przy kościele św. Marcina w Warszawie folwark Pustoły k. Wielkiej Woli i 2 włóki we wsi książęcej Powązki, a warszawskiego klasztoru augustianów 4,5 włóki w książęcym Jazdowie $^{39}$. Przypatrując się strukturze własności szlacheckiej, zauważyć można, że w omawianym czasie w ziemi warszawskiej wsie szlachty zagrodowej (bezkmiecej) stanowiły 30,4 proc. ogółu wsi należących do szlachty. Najwyższy odsetek wsi szlachty nieposesjonatów był $\mathrm{w}$ powiecie

\footnotetext{
${ }^{36}$ Stanowito to 13,2 proc. ogółu wsi należących do książąt (stan na rok 1526), J. Senkowski, Skarbowość, s. 20. Włości książce podlegały starostwu grodowemu w Warszawie oraz dwóm starostwom niegrodowym w Btoniu i Piasecznie; AGAD, ASK I 27, k. 711-711v, 728; SHGWarsz., hasła: Btonie starostwo, s. 12; Piaseczno - klucz dóbr, s. 206. Wspomnieć tu należy o jedynej w tym czasie na Mazowszu własności miejskiej - wieś Solec należała do mieszczan Starej Warszawy, SHGWarsz., s. 269.

${ }^{37}$ Sześć spośród tych wsi stanowito wyodrębnione uposażenie prepozytury kościoła św. Trójcy w Błoniu, AGAD, ASK I 27, k. 712-712v, 728; zob. też: K. Pacuski, Uposażenie klasztoru czerwińskiego w XII-XVI wieku, w: Dzieje klasztoru w Czerwińsku, red. E. Olbromski, Lublin 1997, s. 15-24; M. Stawski, Opactwo czerwińskie w średniowieczu, Warszawa 2007, s. 395-398, Tabela nr 1: Wykaz wsi należących do opactwa w Czerwińsku do końca XV w.

${ }^{38}$ AGAD, ASK I 27, k. 712v, 722; L. Królik, Kapituła kolegiacka w Warszawie do końca XVIII wieku, Warszawa 1990, s. 73-74, 79-80.

${ }^{39}$ SHGWarsz., odpowiednie hasła wg Aneksu; J. Karwasińska, Szpital Świętego Ducha, s. 247; por. W. Pałucki, Przynależność własnościowa osad, s. 93-97.
}

błońskim - 38,4 proc., w warszawskim było to 29,2 proc., w tarczyńskim zaś 26,4 proc. $^{40}$ Ziemia warszawska również posiadała pełną hierarchię urzędniczą, uformowaną jeszcze w XIV w. Analizując obsadę poszczególnych urzędów tej ziemi w omawianym czasie, możemy stwierdzić, że zdecydowaną większość stanowiły osoby pochodzące z ziemi warszawskiej i mające tu swe dobra. Stąd także, jak to zostało wspomniane wyżej, rekrutowali się w znakomitej większości urzędnicy z najbliższego otoczenia Konrada III, a potem jego synów.

Jednopowiatowa ziemia liwska zajmowała w porządku hierarchicznym ziem Mazowsza miejsce za ziemią łomżyńską, jednak w przeciwieństwie do niej posiadała kasztelanię. Kasztelan liwski plasował się na ostatnim miejscu w starszeństwie, po ciechanowskim $^{41}$. Obszar ziemi liwskiej wynosił niewiele ponad $1000 \mathrm{~km}^{2}$. Była ziemią pograniczną - od wschodu graniczyła z Wielkim Księstwem Litewskim, a od południowego wschodu z Królestwem Polskim (z ziemią łukowską województwa lubelskiego $)^{42}$. Pod względem przynależności do administracji kościelnej część północna ziemi należała do archidiakonatu pułtuskiego diecezji płockiej, a południowa - do archidiakonatu warszawskiego diecezji poznańskiej ${ }^{43}$. Ziemia liwska wyodrębniła się z dzielnicy (districtus) czerskiej, a za czas jej ostatecznego

\footnotetext{
${ }^{40}$ Obliczenia na podstawie rejestru poboru podatku tanowego $\mathrm{z} 1528 \mathrm{r}$. W ziemi warszawskiej zanotowano wówczas ogótem 309 wsi szlacheckich, z których 94 znajdowały się w posiadaniu szlachty bezkmiecej (AGAD, ASK I 27, k. 712v-732). Zastrzeżenia i pułapki, jakie rodzi stosowany w źródłach podział szlachty na dwie ww. grupy podatkowe przedstawił W. Pałucki, Przynależność własnościowa osad, s. 100-101; zagadnienie stosowania podziału szlachty na grupy majątkowe omówił ostatnio: K. Boroda, Geografia gospodarcza Królestwa Polskiego w XVI wieku, wyd. 2, Białystok 2018, s. 131-149.

${ }^{41}$ M. Piber-Zbieranowska, Liw - kasztelania, w: Stownik historyczno-geograficzny ziemi liwskiej w średniowieczu [dalej: SHGLiw.], oprac. M. Piber-Zbieranowska, A. Salina, przy wspótpr. E. Kowalczyk-Heyman, red. T. Jurek, Warszawa 2017, s. 108.

${ }^{42}$ T. Jaszczott, Granica pomiędzy ziemiami drohicką i liwską w świetle protokotów komisji z 1546 roku, „Rocznik Liwski”, 6, 2012/2013, s. 13-54; K. Pacuski, Wschodnia granica, s. 27.

${ }^{43} 0$ przebiegu granicy między tymi diecezjami A. Salina, Wstęp, w: SHGLiw., s. VII, oraz M. Piber-Zbieranowska, Liw - dekanat, w: tamże, s. 106-107.
} 
usamodzielnienia się uznać można, jak się wydaje, panowanie Konrada III, który po podziale ojcowizny w 1471 r. obją rządy w księstwie czerskim, obejmującym również teren podległy kasztelanii liwskiej i wprowadził do swojej tytulatury przymiotnik „liwski”" ${ }^{4}$. W tym samym mniej więcej czasie uformował się też tutaj dwuosobowy sąd ziemski: obok sędziego (od 1457 r. działającego samodzielnie ${ }^{45}$ ) pojawił się podsędek liwski, co zdaniem Adama Wolffa stanowiło „charakterystyczną cechę odrębności ziemi; świadectwo, że dana ziemia została już wyjęta $z$ dawnego związku terytorialnego i że powstało nowe centrum" ${ }^{46}$. Choć początki kasztelanii liwskiej datować można na przełom XIII i XIV w. ${ }^{47}$, ciagłe osadnictwo w ziemi liwskiej miało stosunkowo młodą metrykę. Jej tereny w większości kolonizowane były dopiero w ciągu XV w., a wiele osad powstało już w kolejnym stuleciu. Nadania książęce obszarów leśnych otrzymywała tu szlachta pochodząca przede wszystkim z ziem czerskiej i zakroczymskiej ${ }^{48}$. Północno-zachodnią część ziemi porastała rozległa Puszcza Korycka, stanowiąca część większego kompleksu leśnego złożonego z Puszcz Jadowskiej, Łochowiec i Sulejowskiej. Za czasów ostatnich książąt mazowieckich tereny te nie były jeszcze w zasadzie trzebione i zajmowane pod osadnictwo $^{49}$.

\footnotetext{
${ }^{44}$ M. Piber-Zbieranowska, Liw - terytorium i ziemia, w: SHGLiw., s. 122 0 tytulaturze liwskiej w dokumentach Konrada III Rudego, zob.: J. Grabowski, Tytulatura na dokumentach książąt mazowieckich. Forma i funkcje (wybrane zagadnienia), „Klio”, 13, 2009, s. 49

${ }^{45}$ Do 1457 r. urząd sędziego liwskiego połączony był z urzędem kastelana liwskiego, M. Piber-Zbieranowska, Liw - kasztelania, w: SHGLiw., s. 108.

${ }^{46} \mathrm{~A}$. Wolff, Studia, s. 55. Pierwsza wzmianka o podsędku liwskim pochodz z 1474 r. Więcej 0 tym: M. Piber-Zbieranowska, Liw - powiat sądowy, w: SHGLiw., s. 109-110.

${ }^{47}$ E. Kowalczyk, Osadnictwo ziemi liwskiej do połowy XIV w. w świetle źródet pisanych, w: Stowiańszczyzna w Europie średniowiecznej, t. 2 red. Z. Kurnatowska, Wrocław 1996, s. 193-197; taż, Najstarsze nazwy miejscowe ziemi liwskiej, „Rocznik Liwski”, 7, 2014, s. 9-16; M. Piber-Zbieranowska, Liw - kasttelania, s. 107.

${ }^{48}$ T. Jaszczott, Naphyw rycerstwa do pótnocnej części ziemi liwskiej w XV i początkach XVI wieku (parafie Korytnica i Pniewnik), „Zeszyty Korytnickie", 4, 2011, s. 143-169.

${ }^{49}$ Więcej 0 tym: M. Piber-Zbieranowska, [Puszcza Korycka], w: SHGLiw. s. $175-176$.
}

W omawianym czasie nie można mówić o istnieniu sieci miejskiej w ziemi liwskiej. Do 1530 r. funkcjonowały tu bowiem zaledwie dwa miasta ${ }^{50}$. Pod względem własnościowym dominowały tu dobra szlacheckie, a wśród nich (zwłaszcza w części południowej) dobra drobnej szlachty, które w ciągu XVI w. uległy dalszemu rozdrobnieniu, stając się gniazdami szlachty zagrodowej i cząstkowej. Istniały tu również włości jedno- lub kilkuwioskowe należące do średniej szlachty, a nawet nielicznych rodzin dygnitarskich ${ }^{51}$. Ich majętności nie ograniczały się jednak jedynie do posiadłości w ziemi liwskiej. Według zapisów pierwszego w pełni zachowanego rejestru poborowego z $1540 \mathrm{r}^{52}$ na 130 spisanych w ziemi liwskiej wsi do szlachty należało 121 (w tym jedna w części). Z tej liczby 67 znajdowało się w posiadaniu szlachty bezkmiecej, czyli niemal 55,4 proc. osad szlacheckich ${ }^{53}$. W rękach książęcych znajdowały się wspomniane dwa miasta i sześć całych wsi (oraz jedna w części), zarządzanych przez starostę liwskiego ${ }^{54}$. Około 1526 r. posiadłości kościelne w ziemi liwskiej były znikome. Własność biskupa poznańskiego stanowiły dwie wsie, jedna wieś należała do plebana kościoła parafialnego w Liwie Starym ${ }^{55}$.

50 Był to Liw Stary i Liw Nowy. W 1530 r. lokowane zostało miasto Dobre, przez właściciela gruntów, Jana Dobrzynieckiego, podstolego zakroczymskiego, M. Piber-Zbieranowska, Dobre, w: SHGLiw., s. 26-30.

${ }^{51}$ A. Salina, Wstęp, w: SHGLiw., s. VII; zob. też: A. Żaboklicka, Zmiany w strukturze drobnej wtasności szlacheckiejXV-XVI w. na przykładzie ziemi liwskiej, „Przegląd Historyczny”, 49 (2), 1958, s. 250-260.

${ }^{52}$ Rejestr poborowy z $1535 \mathrm{r}$. zachował się jedynie we fragmencie zawierającym podatek od wsi szlachty bezkmiecej (AGAD, ASK I 39, k. 33-36).

${ }^{53}$ AGAD, ASK I 46, k. 80-85v.

${ }^{54}$ Ok. 1525 r. były to: Czerwonka, Korytnica, Wola Korycka, Krypy, Popowo, Grodzisko i części wsi Zawady (która jeszcze przed 1540 r. została przekształcona w folwark); do starostwa liwskiego należała też wieś Turek w powiecie warszawskim (M. Piber-Zbieranowska, Liw - starostwo, w: SHGLiw., s. 110-122). Jerzy Senkowski (Skarbowość, s. 20) podaje, że w ziemi liwskiej było osiem wsi książęcych, być może wliczając tu przygraniczny Turek. ${ }^{55}$ A. Salina, Grębków, w: SHGLiw., s. 38; taż, Podsusze, tamże, s. 156; M. Piber-Zbieranowska, Wyczótki, tamże, s. 232. Inaczej niż SHGLiw., uważam, że Wola Grębkowska również stanowiła własność duchowną, choć w $1526 \mathrm{r}$. zapewne jeszcze nie istniała, gdyż po raz pierwszy pojawia się w rejestrze 1540 r. (AGAD, ASKI 46, k. 80; A. Salina, Wola Grębkowska, w: SHGLiw., s. 227).Z tego samego rejestru pochodzi też pierwsza wzmianka 0 należącej do biskupa poznańskiego Żarnówce (AGAD, ASK I 46, k. 80). 
Hierarchia urzędnicza ziemi liwskiej, formująca się od przełomu XIV i XV w., u progu XVI w. była jeszcze niepełna. W 1503 r., poza kasztelanem wśród urzędników tej ziemi widzimy jedynie sędziego, podsędka i wojskiego ${ }^{56}$. Kolejne urzędy, wymieniając je według starszeństwa cześnik, chorąży i podkomorzy - utworzone zostały przed 1526 r., a przypisać to można przede wszystkim działaniom księżnej Anny Radziwiłłówny, występującej tu przypuszczalnie nie jako regentka, lecz raczej jako posiadaczka oprawy wdowiej z ośrodkiem w Liwie ${ }^{57}$. Pierwsza wzmianka o znanym z imienia i nazwiska podkomorzym liwskim pochodzi z 1509 r., kiedy z urzędem tym wystąpił Stanisław Wojsławski ${ }^{58}$. Pierwsze poświadczenie cześnika liwskiego pochodzi zaś z 13 marca 1525 r. Urząd ten sprawował wówczas Jan Ojrzanowski h. Prus, starosta warszawski ${ }^{59}$. Powierzenie mu od razu urzędu cześnika, z pominięciem zwykłego cursus honorum, stanowiło ogromny awans i musiało być nagrodą od Janusza III albo za jakieś bieżące, nieznane nam bliżej zasługi, albo też dowodem uznania za wieloletnią służbę ojca Jana - też Jana z Ojrzanowa, kasztelana warszawskiego (zm. w 1511 r.) - na rzecz matki księcia w czasie jej regencji. Tak czy inaczej, stwierdzić trzeba, że urząd cześnika liwskiego stworzono najpewniej specjalnie dla starosty Jana Ojrzanowskiego. Po jego śmierci we wrześniu 1526 r. urzędu tegoż już nie obsadzono. Ponownie, tym razem już na stałe, w hierarchii liwskiej cześnik pojawia się dowodnie dopiero

\footnotetext{
${ }^{56}$ Spis osób, które do połowy XVI w. petnity poszczególne urzędy podaje: M. Piber-Zbieranowska, Liw - kasttelania oraz Liw - powiat sądowy, w: SHGLiw., s. 108-110; zob. też: taż, Liw - terytorium i ziemia, tamże, s. 123.

${ }^{57}$ W akcie z 1499 r., w którym ks. Konrad podawał wykładnię dokumentu z 1497 r. wyznaczającego księżnej Annie oprawę wdowią, w ustępie dotyczącym mianowania urzędników książę stwierdza, że księżna w tej kwestii „,habebit et ha b et [podkreślenie - M.P.-Z.] omnem facultatem" (IMT, t. 2, nr 160). Co według mnie oznacza, że wpływ na obsadę urzędów w ziemiach jej oprawy księżna uzyskała już w momencie ustanowienia jej zaopatrzenia wdowiego.

${ }^{58}$ AGAD, Metryka Koronna [dalej: MK] 32, k. 192v: 15 |l 1509 r.

${ }^{59}$ AGAD, MK 41, k. 33v; MK 60, k. 256v.
}

w roku $1539^{60}$. Tuż przed ostateczną inkorporacją Mazowsza do Korony w hierarchii urzędów w ziemi liwskiej utworzono urząd chorążego. W maju 1526 r. z urzędem tym występuje Piotr Prażmowski h. Belina ${ }^{61}$. Mimo że był to czas rządów księżniczki Anny Konradówny, która po śmierci brata przejęła krótkotrwale władzę na Mazowszu, utworzenie urzędu i powierzenie go Piotrowi trzeba przypisać jeszcze Januszowi III. Było to niewątpliwie nagrodą książęcą dla ojca wspomnianego - Wawrzyńca Prażmowskiego, wówczas kasztelana czerskiego, za jego wieloletnią służbę pełnioną jeszcze za panowania Konrada III. Wawrzyniec był jednym z najbliższych współpracowników księcia Janusza, wyznaczonym na wykonawcę jego testamentu ${ }^{62}$. Piotr Prażmowski poświadczony jest jako chorąży liwski do 1537 r., sprawował ten urząd zapewne dożywotnio ${ }^{63}$.

Do końca panowania Konrada III szlachta pochodząca z ziemi liwskiej miała niewielkie znaczenie, nawet przy obsadzie urzędów tejże ziemi ${ }^{64}$. Zmianę tej sytuacji przyniosły rządy Anny Radziwiłłówny, a potem jej synów. W latach 1503-1526 widać wyraźny wzrost udziału przedstawicieli szlachty tej ziemi w zarządzie księstwem, zarówno na szczeblu lokalnym, jak i też ogólnopaństwowym. Były to jednak przypadki jednostkowe (Andrzej i Michał Zaliwscy, Mikołaj Żukowski, Gotard z Niwisk), a w omawianym czasie z ziemi liwskiej nie wywodziła się żadna rodzina, którą zaliczylibyśmy do mazowieckiej elity możnowładczej ${ }^{65}$.

\footnotetext{
${ }^{60}$ AGAD, MK 60, k. 48v

${ }^{61}$ AGAD, Zakroczymskie ziemskie wieczyste relacje, 14, k. 416v. Wcześniej był starostą zakroczymskim (I. 1522-1523; tamże, 11, k. 761, 765v).

${ }^{62}$ K. Pacuski, Prażmowski Wawrzyniec, w: Polski stownik biograficzny, t. 28, Wrocław 1984-1985, s. 392.

${ }^{63}$ W. Knapiński, Notaty do historii kościołów warszawskich, Warszawa 1949 (Materiały do Dziejów Sztuki i Kultury Państwowy Instytut Historii Sztuki, 6), mps powielony, s. 56.

${ }^{64}$ K. Pacuski, Elita władzy ziemi liwskiej w XV w., „Rocznik Liwski”, 1, 2005/2006, s. 92.

${ }^{65}$ Więcej 0 tym: M. Piber-Zbieranowska, Udział szlachty ziemi liwskiej w zarządzie księstwem mazowieckim w latach 1503-1526. Wybrane przykłady, „Rocznik Liwski”, 8, 2015, s. 133-147.
} 
Pozycja ziemi nurskiej względem dwóch innych ziem księstwa mazowieckiego łomżyńskiej i makowsko-różańskiej, które, podobnie jak ona, w ramach swej hierarchii urzędniczej nie posiadały kasztelanii, nie została dotąd do końca rozpoznana i stanowić powinna przedmiot pogłębionych badań. Przyjmuję hierarchię zamieszczoną w pracy Bogdana Sobola o mazowieckim parlamentaryzmie doby książęcej, opracowaną przez niego na podstawie najczęściej pojawiającego się w źródłach porządku, według którego wymieniani byli urzędnicy ziemscy uczestniczący w zjazdach, tj. następującą kolejność ziem: łomżyńska, nurska i makowsko-różańska. Według starszeństwa przyjętego przez tegoż badacza, między ziemią łomżyńską a nurską znajdowała się jeszcze ziemia liwska ${ }^{66}$.

Ziemia nurska podzielona była na trzy powiaty: nurski, ostrowski i kamieniecki, które łącznie zajmowały niemal $3500 \mathrm{~km}^{2}$ powierzchni ${ }^{67}$. Wschodnia granica tej ziemi stanowiła równocześnie granicę Mazowsza z Wielkim Księstwem Litewskim. Jak wspomniano wyżej, obszar ten wyodrębnił się z dzielnicy warszawskiej, jednak jeszcze u schyłku XV i na początku XVI w. w źródłach czasem używano dla tego terenu określenia districtus Varsoviensis ${ }^{68}$ bądź spisywano go, traktując jako część ziemi warszawskiej ${ }^{69}$. W ramach struktur

\footnotetext{
${ }^{66}$ B. Sobol, Sejm i sejmiki ziemskie na Mazowszu książęcym, Warszawa 1968, s. 164. Wyżzzą pozycję ziemi tomżyńskiej w stosunku do liwskiej potwierdzają nie tylko zestawiania osób uczestniczących w zjazdach księstwa analizowane przez Bogdana Sobola, lecz także ścieżki awansu urzędników, zob. część druga niniejszego tekstu.

${ }^{67}$ Podział ziemi nurskiej na powiaty nastąit prawdopodobnie wXV w., A. Wolff, Studia, s. 24. Powiat kamieniecki dominował pod względem zasięgu, obejmując ponad 2 tys. km². Przy okazji warto tu zwrócić uwagę na błąd, który wkradł się do tabeli pt. Podziat administracyjny Rzeczypospolitej Obojga Narodów po 1569 roku, stanowiącej Aneks do artykułu K. Chłapowskiego, Granice i podziaty administracyjne Królestwa Polskiego i Rzeczypospolite Obojga Narodów w XV_XVIII wieku, ,Studia Geohistorica”, 7, 2019, s. 182 do ziemi łomżyńskiej zaliczono tam powiat ostrowski, w rzeczywistości należący do ziemi nurskiej, powiat ostrołęcki zaś, wchodzący w skład ziemi tomżyńskiej, mylnie zaliczono do ziemi nurskiej.

${ }^{68}$ AGAD, MK 32, k. 38; K. Pacuski, Warszawa - districtus, w: SHGWarsz. S. 297.

${ }^{69}$ AGAD, ASK I 27, k. 459v; ASK I 40, k. 122; AGAD, Varia Oddziału I, sygn. 7 , „Villae et bona ducalia obligata et alienata per olim dominos duces et dominam ducem Annam in toto ducato Masouie", k. 146-146v.
}

administracji kościelnej niemal cała ziemia znajdowała się w granicach archidiakonatu pułtuskiego diecezji płockiej. Jedynie niewielki skrawek, obejmujący w omawianym czasie część mocno rozdrobnionej już włości Długa Dąbrowa, przynależał do diecezji łuckiej (dekanat brański w archidiakonacie brzeskim $)^{70}$.

Systematyczne badania nad rozwojem osadnictwa w ziemi nurskiej nie były dotąd szerzej podejmowane ${ }^{71}$, a ich przeprowadzenie wykracza poza ramy tej pracy. Analizując sondażowo dostępny materiał źródłowy, zgromadzony w Kartotece Słownika historyczno-geograficznego Mazowsza w średniowieczu oraz opracowania, również z zakresu archeologii, możemy stwierdzić, że w okresie średniowiecza najwcześniej, przypuszczalnie już od X w., zasiedlane były tereny nad dolną Narwią i Bugiem oraz Orzem i Brokiem, co poświadczają pozostałości grodów z podgrodziami i osad wiejskich stanowiących ich zaplecze (np. grodzisko w Święcku z XI-XII w.) ${ }^{72}$. Fundację kościoła św. Idziego w Wyszkowie (najstarszą na Pobużu) datuje się na koniec XI w. Jego uposażenie stanowiły początkowo dochody z komory celnej na szlaku nadbużańskim ${ }^{73}$. Stan i zasięg

\footnotetext{
${ }^{70}$ Około połowy XVI w. na części włości Długa Dąbrowa, która znalazła się po mazowieckiej stronie granicy, wydzielity się dwie wsie - Dąbrowa-Nowawieś i Dąbrowa-Modzele, pozostała część okolicy szlacheckiej Dąbrowskich, w tym siedziba parafii - Długa Dąbrowa, należała do powiatu drohickiego, T. Jaszczott, Naptyw rycerstwa i szlachty na pogranicze mazowiecko-podlaskie w XV i pierwszej połowie XVI wieku (obszar dzisiejszego powiatu wysokomazowieckiego), w: Rody, rodziny Mazowsza i Podlasia. Źródła do badań genealogicznych, red. D.K. Rembiszewska, H. Krajewska, Łomża 2013, s. 207-210.

${ }^{71} 0$ osadnictwie w parafiach Czyżewo i Rosochate w pow. nurskim zob. T. Jaszczott, Napływ rycerstwa i szlachty, s. 226-233. 0 Wyszkowie i jego parafii: Ecclesia Viscoviensis. Dzieje parafii św. Idziego w Wyszkowie, red. Z. Morawski, M. Przytocka, Puttusk 2006 (zob. niżej).

${ }^{72}$ J. Wiśniewski, Początek i rozwój nowego osadnictwa w ziemi łomżyńskiej w końcu XIV i w XV wieku, „Studia Łomżyńskie”, 1, 1989, s. 23-28; E. Kawałkowa, Osadnictwo pradziejowe i średniowieczne $w$ dolinie dolnej Narwi, w: Narew w dziejach i wspótczesności Mazowsza i Podlasia, red. A. Dobroński, W. Grębecka, Łomża 2004, s. 163-164 oraz ryc. 1 i 2 , s. 171-172; A. Gieysztor, Trzy stulecia najdawniejszego Mazowsza (połowa X-potowa XIII w.), w: Dzieje Mazowsza, t. 1, s. 133-134.

${ }_{73}$ Później jego uposażenie stanowity też dziesięciny z piętnastu osad na Pobużu, poświadczonych w dokumencie biskupa płockiego Ścibora z 1388 r., szerzej o tym K. Pacuski, Dzieje osady i parafii [Wyszków] w średniowieczu, w: Ecclesia Viscoviensis, s. 29-46.
} 
osadnictwa omawianego obszaru na początku XIII w. znany jest dzięki najstarszemu spisowi dóbr biskupstwa płockiego, datowanemu przez Kazimierza Pacuskiego na przełom XII i XIII w. ${ }^{74}$ Okres od końca XII w. aż po drugą połowę wieku XIV to na omawianym terenie czas wyniszczających najazdów pogańskich, które spowodowały niemal całkowite wyludnienie tych terenów i porastanie ich na powrót puszczą ${ }^{75}$. Osadnictwo zaczęło się odradzać na większą skalę dopiero w końcowych dziesięcioleciach XIV w., podobnie jak poprzednio, najwcześniej w dolinach wspomnianych rzek. Panowanie księcia Janusza I (od 1381 r., tj. po śmierci ojca, gdy rządził jako władca samodzielny), to czas intensywnej kolonizacji terenów na północ i północny-zachód od Nura, z których, zapewne w trzecim dziesięcioleciu XV w., wydzielił się powiat nurski ${ }^{76}$. W XVI w., na skutek wzmożonych podziałów własnościowych, osadnictwo tu było poważnie rozdrobnione, co wiązało się ze znacznym jego zagęszczeniem ${ }^{77}$. W końcu $\mathrm{XIV}$ i w pierwszej ćwierci XV w. zasiedlano również tereny wokół Ostrowi. Na terenach centralnych powiatów kamienieckiego i ostrowskiego natomiast, porośniętych gęstymi lasami, proces osadniczy rozpoczął się później, a jego nasilenie przypadło na drugą połowę wieku XV i cały XVI. Specyfika fizjograficzna i własnościowa (o czym poniżej) tego obszaru sprawiła, że przeważały tu osady o dużych rozmiarach, lecz rzadko rozmieszczone ${ }^{78}$.

\footnotetext{
${ }^{74}$ Codex diplomaticus et commemorationum Masoviae generalis [dalej: KDMaz.], wyd. J.K. Kochanowski, Warszawa 1919, nr 301, s. 342-348 (falsyfikat formalny, tekst z drugiej połowy XIII w.), tu zestawienie wcześniejszych edycii; 0 datowaniu inwentarza: K. Pacuski, Uposażenie klasztoru, s. 22, przyp. 5; tenże, Dzieje osady, s. 31-33.

75 J. Wiśniewski, Początek i rozwój nowego osadnictwa, s. $28,33$.

${ }^{76}$ Dwuosobowy sąd ziemski (ț. złożony z sędziego i podsędka) poświadczony jest od 1434 r., A. Wolff, Starszeństwo urzędów. Metoda ustalania na przykładzie hierarchii Mazowsza udzielnego, Warszawa 1928, nr 64: podsędek nurski Krystyn tacny z Obrytego.

77 Por. H. Rutkowski, Lokalizacja miejscowości, w: AHPMaz., cz. 2, s. 76.

${ }^{78}$ Liczba osad w powiecie kamienickim przypadająca na $100 \mathrm{~km}^{2}$ była jedną z najniższych na Mazowszu (stan na drugą połowę XVI w., tamże, s. 76); mniejsze zagęszczenie miały tylko powiaty ostrołęcki i kolneński (zob. część
}

U progu XVI w. w ziemi nurskiej funkcjonowało pięć miast, z czego aż cztery położone były nad Bugiem: Nur, Brok, Kamieniec (ob. Kamieńczyk) i Wyszkowo ${ }^{79}$. Duży obszar tej ziemi powodował jednak, że gęstość sieci miejskiej była jedną z najniższych w księstwie. Struktura własności omawianego obszaru i jej rozmieszczenie są dość interesujące. W powiecie nurskim znacząco dominowały wsie szlachty ubogiej. W 1528 r. na 113 wsi szlacheckich, aż 102 znajdowały się w posiadaniu szlachty bezkmiecej (90,2 proc.). Wsie te były też bardzo rozdrobnione - niemal jedna czwarta (24 wsie) miała dziesięciu i więcej właścicieli ${ }^{80}$. Cała zachodnia część tegoż powiatu należała zaś do biskupstwa płockiego, tworząc rozległy klucz dóbr z ośrodkiem w Złotoriii ${ }^{81}$. Posiadłości mieli tu również kanonicy regularni z Czerwińska $(4 \text { wsie })^{82}$ i kapituła pułtuska $(3 \text { wsie })^{83}$. Do książąt należało miasto Nur z wsią Zaszków $^{84}$. W powiecie ostrowskim własności duchownej nie było w ogóle, do książąt zaś należało tylko miasto Ostrowia $^{85}$. Wsi szlacheckich było w sumie 59, z czego niemal dwie trzecie znajdowały

druga niniejszego tekstu). Na temat zależności wielkości osad od ich własności, zob.: J. Wiśniewski, Początek i rozwój nowego osadnictwa, s. 70-71.

${ }^{79}$ Miasto Andrzejów, należące do biskupów płockich, założone zostało już po inkorporacji Księstwa Mazowieckiego, we wsi Wronie. W 1528 r. zezwolenia na lokację udzielitZygmunt I, S. Pazyra, Geneza i rozwój miast mazowieckich, Warszawa 1959, s. 122.

${ }^{80} \mathrm{~W}$ dziewiętnastu wsiach własność podzielona była na 10-15 działów, w trzech na 16-17, w jednej wsi (Świercze) na 23, w jednej (Sienica Wielka) na 32 dziaty, AGAD, ASK I 27, k. 744v-765v.

${ }^{81}$ Do tegoż klucza należało w omawianym czasie osiemnaście wsi. Miasto Brok, położone nad Bugiem tuż przy zachodniej granicy powiatu, wchodzito w skład wyszkowskiego klucza dóbr (zob. dalej); obliczenia na podstawie Kartoteki Wolffa (pow. nurski) oraz Kartoteki Atlasu Historycznego Polski, przechowywanej w IH PAN w Warszawie. W rejestrze poboru łanowego z 1528 r. wsi biskupich nie spisano.

82 KDMaz. nr 301; Nowy kodeks dyplomatyczny Mazowsza, t. 2, wyd. I. Sutkowska-Kuraś, S. Kuraś, współpr. K. Pacuski, H. Wajs, Warszawa 1989, nr 16, 249; AGAD, ASK I 27, k. 743v; K. Pacuski, Wschodnia granica, s. 26-27.

${ }^{83}$ Kartoteka Wolffa, pow. nurski; zob. Aneks.

${ }^{84}$ Wcześniej Zaszków stanowił własność klasztoru w Czerwińsku, nadaną mu zapewne w związku z fundacją książęcą w połowie XII w., K. Pacuski, Wschodnia granica, s. 26.

${ }^{85} \mathrm{~W}$ omawianym czasie w ziemi nurskiej funkcjonowały dwa starostwa grodowe w Nurze oraz niegrodowe w Ostrowi, które utworzone zostało jednak dopiero w 1523 r. Do 1495 r. istniało również starostwo niegrodowe w Kamieńcu, jednak po objęciu ziemi nurskiej przez Konrada III (po śmierci jego brata Janusza II), zostało przez niego włączone do starostwa nurskiego 
się w rękach szlachty posesjonatów. Osady szlachty bezkmiecej zaś nie były tak rozdrobnione jak w powiecie nurskim. Większość z nich miała od trzech do sześciu właścicieli, tylko w trzech zanotowano powyżej dziesięciu działów ${ }^{86}$. Zbliżona była struktura własności szlacheckiej w powiecie kamienieckim, choć tu przewaga wsi szlachty osiadłej była jeszcze większa. $\mathrm{Na}$ 64 wsie szlacheckie 53 stanowiły własność szlachty posesjonatów ( $\mathrm{w}$ tym $\mathrm{w}$ siedmiu zanotowano działy szlachty bezkmiecej ${ }^{87}$ ). Osady szlachty nieposiadającej były nieduże, podzielone z reguły na dwa-trzy dzia$\mathrm{ły}^{88}$. Powiat kamieniecki przedzielony był na dwie niemal równe części linią Bugu, w części prawobrzeżnej, tj. północnej, poza kilkunastoma wsiami szlacheckimi istniejące osady należały do dwóch kluczy dóbr biskupstwa płockiego - z ośrodkami w Wyszkowie (2 miasta i 15 wsi) i w Puttusku (10 wsi). Włości te, między Piasecznicą a Bugiem, porastały w dużej części lasy Puszczy Białej. Swoje dobra mieli tu też: kapituła pułtuska ( 9 wsi, w tym 1 osada młyńska), norbertanki płockie (3 wsie), benedyktyni św. Wojciecha w Płocku (1wieś) i kościół parafialny w Kamieńcu (1 wieś) ${ }^{89}$. W części południowej natomiast, obok skupisk majętności szlacheckich (parafie: Dąbrówka, Niegowo i Podstoliska na zachodzie oraz Kamionlas i Stoczek na wschodzie), własność książęcą stanowił spory kompleks dóbr z ośrodkiem w Kamieńcu, obejmujący Puszcze Kamieniecką i Jadowską rozdzielone rzeką Liwiec ${ }^{90}$.

(więcej: M. Piber-Zbieranowska, Księżna mazowiecka, s. 438-439). Po inkorporacji starostwo w Kamieńcu przywrócono.

${ }^{86}$ Według danych z 1528 r.: 38 wsi szlachty posiadającej, 20 wsi szlachty zagrodowej, w jednej wsi - Dzwonek, obok wtók osiadłych, był dział bezkmiecy; AGAD, ASK I 27, k. 739-742v. We wsiach Guty i Żmiłowo było czternastu właścicieli, w Gocłach - trzynastu.

${ }^{87}$ W czterech wsiach byty to pojedyncze działy; we wsiach Popowo, Łazy i Dąbrowa Nowa zanotowano odpowiednio cztery i po dwa działy szlachty bezkmiecej.

${ }^{88}$ Dwie wsie (Budziska i Kalinowo) były jednodziałowe, w Ciskach zanotowano cztery, a w Czarnowie pięć działów, AGAD, ASK I 27, k. 734v-736v.

${ }^{89}$ Kartoteka Wolffa, powiat kamieniecki; zob. Aneks. 0 wyszkowskim kluczu dóbr zob. D. Gimpel, Dzieje Wyszkowa, Warszawa 1984, s. 59-67.

${ }^{90}$ Ze spisu dochodów panującego sporządzonego dla Mazowsza wkrótce po inkorporacji w 1526 r., wiadomo, że aż osiem wsi (spośród trzynastu
$\mathrm{Na}$ terenie między Bugiem a rzeką Ugoszcz istniało wówczas sześć wsi należących do kapituły kolegiackiej w Warszawie ${ }^{91}$.

Hierarchia urzędnicza ziemi nurskiej formowała się od pierwszej połowy XV w., lecz w momencie śmierci księcia Konrada III (1503 r.) była jeszcze bardzo niepełna. U progu XVI w. funkcjonowały w tej ziemi urzędy: cześnika, sędziego, podsędka i wojskiego $^{92}$. Za rządów Konradowiców nie dodano do tej hierarchii żadnego nowego urzędu. Twierdzenie Kazimierza Pacuskiego, że w 1524 r. utworzono urząd podczaszego nurskiego ${ }^{93}$, wymaga, jak sądzę, skorygowania. Istotnie 6 stycznia $1524 \mathrm{r}$. jako świadka czynności książęcych w Nurze zanotowano Stanisława ze Zgleczewa podczaszego nurskiego ${ }^{94}$. Przypuszczam jednak, że nastąpiła tu pomyłka. Stanisław Zgleczewski w latach 1511-1519 pełnił dowodnie urząd podsędka nurskiego ${ }^{95}$. Adam Wolff, analizując drogę awansu urzędników mazowieckich, ustalił, że w istniejącej tu hierarchii podczaszy zajmował przedostatnią pozycję (przed podstolim), a podsędek plasował się o dwa szczeble wy$\dot{z ̇ e j}^{96}$. Dlatego też przejście Zgleczewskiego z urzędu podsędka na podczaszego jest bardzo mało prawdopodobne, ponieważ nie byłby to awans, lecz raczej degradacja. Ze źródeł znane są natomiast awanse

przynależnych wówczas do Kamieńca) książęta lokowali dopiero w latach 1513-1524; niemal wszystkie miały po kilkanaście i więcej włók: Sytne - 20 wtók, Chrzęsne - 22, Gwizdały - 18, Nadkole - 6, Wielgie - 26, Brzoza - 18, Sulewo - 17, Wujowa Łąka - 13 (AGAD, ASKI 40, k. 124-127; MK 8, k. 24). W pozostałych pięciu wsiach (Tłuściec, Jadowo, Płatkownica, Morzyczyn i Skuszewo) było w sumie 77 wók; AGAD, ASK I 27, k. 733.

${ }^{91}$ Acta ecclesiae collegiatae Varsoviensis, wyd. B. Ulanowski, Kraków 18971926 (Archiwum Komisji Prawniczej, 6), nr 46, s. 54-56; L. Królik, Kapituła kolegiacka, s. 74. Wieś Ugoszcza (Mrozowa Wola) założona została krótko przed 1521 r. Wiadomość o lokacji kolejnych dwóch wsi -Zieleńca i Sokółki, pochodzi z 1535 r., Kartoteka Wolffa, pow. kamieniecki (odpowiednie hasła). 0 wschodniej granicy tych dóbr, będącej też granicą ziemi i państwa zob. A. Dunin-Wąsowiczowa, Podziaty administracyjne, s. 38-39.

${ }^{92}$ W drugiej połowie XV w., w latach 1469-1474 oraz 1478-1482, poświadczony jest skarbnik nurski (A. Wolff, Starszeństwo, nr 64; Pacuski, Spis). Po tym czasie jednak urząd ten już się nie pojawia.

${ }^{93}$ K. Pacuski, Warszawa - districtus, w: SHGWarsz., s. 297.

${ }^{94}$ AGAD, MK 32, k. 206.

${ }^{95}$ AGAD, Księgi grodzkie i ziemskie warszawskie, sygn. 10, s. 831; MK 32, k. 209v.

${ }^{96}$ A. Wolff, Studia, s. 57; tenże, Starszeństwo, nr 97. 
z podczaszego na podsędka, przykładem może być tu Jan Rembiertowski podczaszy warszawski (1505-1508), a następnie podsędek warszawski (1509-1510) i w końcu sędzia warszawski (1510-1521) ${ }^{97}$. Stanisław Zgleczewski w 1524 r. piastował przypuszczalnie urząd cześnika nurskiego. Jest to możliwe z dwóch co najmniej powodów. Po pierwsze, nie mamy potwierdzonej innej obsady tego urzędu w tym czasie. W latach 1496-1520 jako cześnik nurski w źródłach występuje Bronisz z Grodziska, a w latach 1525-1533 Florian Parys z Sieczczy ${ }^{98}$. Po drugie, kolejne poświadczenie źródłowe istnienia urzędu podczaszego nurskiego pochodzi dopiero z drugiej połowy XVI w. ${ }^{99}$ Kolejne urzędy w hierarchii ziemi nurskiej powstały również dopiero w tym okresie lub już w XVII w. ${ }^{100}$
Przedstawiona wyżej charakterystyka czterech ziem Księstwa Mazowieckiego, powiązanych ze sobą swoją genezą, stanowiąca pierwszą część przeglądu ziem wchodzących w skład Księstwa tuż przed jego włączeniem do Korony, pokazuje spore zróżnicowanie w stopniu zagospodarowania poszczególnych obszarów, spowodowane po części specyfiką środowiska naturalnego, ale w znacznej mierze uwarunkowaniami historycznymi. Zamieszczone tu dane, zwłaszcza te dotyczące stosunków własnościowych, w zestawieniu z dość dobrze rozpoznaną sytuacją w końcu XVI w. ${ }^{101}$, stanowić mogą punkt wyjścia do badań nad zmianami, które zaszły w strukturze ekonomiczno-społecznej Mazowsza w ciągu XVI stulecia.
${ }^{97}$ W źródłach występował też jako Brwinowski lub Kopański, od swoich włości: Rembertowa, Brwinowa i Kopanej w ziemi warszawskiej, M. Piber-Zbieranowska, Księżna mazowiecka, s. 545-547.

${ }^{98}$ AGAD, MK 340, 104v; Matricularum Regni Poloniae summaria [dalej: MRPS], t. 4/2, wyd. T. Wierzbowski, Warszawa 1912, nr 16722; M. Piber-Zbieranowska, Księżna mazowiecka, s. 542.

${ }^{99}$ W. Wittyg, Nieznana szlachta polska i jej herby, Kraków 1908, s. 234.

${ }^{100}$ W kolejności chronologicznej pojawienia się w źródłach był to: stolnik (1564 r., MRPS, t. 5/1, Warszawa 1919, nr 3014); podkomorzy (1569 r., A. Boniecki, Herbarz polski, t. 16, Warszawa 1913, s. 185), chorąży (1575 r., Regestra thelonei aquatici Wladislaviensis saeculi XVI, wyd. S. Kutrzeba, F. Duda, Kraków 1915, s. 329), towczy (1610 r., A. Boniecki, Herbarz polski, t. 7, Warszawa 1904, s. 191).
101 W. Pałucki, Przynależność własnościowa osad, s. 88-102; D. Główka, Wieś na Mazowszu w XVI-XVI wieku, w: Dzieje Mazowsza, t. 2, s. 167-195. 


\section{ANEKS}

\section{Dobra w posiadaniu instytucji kościelnych ok. $1526 \mathrm{r}$. (Księstwo Mazowieckie, część południowa)}

W nawiasach podano nazwy współczesne, jeśli różnią się od szesnastowiecznych wyraźnie lub w sposób utrudniający identyfikację. Wymieniając poszczególne ziemie, zastosowano porządek przyjęty w publikacji.

1. Arcybiskupstwo gnieźnieńskie

- ziemia czerska

○ powiat warecki: Konary, Ostrówek, Podgórzyce, Pólko, Przylot

2. Biskupstwo płockie

- ziemia warszawska

o powiat warszawski: Chotomów, Jabłonna, Janowo, Radziszewo (Rajszew)

- ziemia nurska

o powiat nurski: Brok - miasto, Biel, Daniłowo, Dąbrowa, Gaczkowo, Glina, Janowo (Mianowo), Kaczkowo, Kalinowo, Kańkowo, Łętownica, Małkinia, Ostrożne, Pęchratka, Ruskołęki, Srebrna, Wronie, Złotoria, Żabikowo [klucz złotorski]

○ powiat kamieniecki: Wyszkowo - miasto, Biskupie, Brańsk, Nagoszewo, Osuchowo, Pecyna, Poręba, Porządzie, Rząśnik, Trzcianka, Tuchlino, Turzyno, Udrzyno, Wielątki Wiśniewo, Wólka Wyrzykowa (Wólka Przekory) [klucz wyszkowski]; Bartodzieje, Ciołkowo, Drwały, Gładczyno (część), Gródek, Lutobrok, Pniewo, Psary, Skłody (Skłudy), Wielgolas [klucz pułtuski]

3. Biskupstwo poznańskie

- ziemia czerska

o powiat czerski (część prawobrzeżna): Borek, Chromin, Jemielno, Kawczyn, Kisielsk, Kobiałki (ob. Stare Kobiałki), Prawda, Smoniewice Biskupie (ob. Szymoniewice Duże), Sobienie, Stoczek (inaczej Poznańska Wola), Wola Chromska (potem Łopacianka?), Wola Kisielska; niezidentyfikowane: Wola, Bienki, Pociekraw

$\circ$ powiat grójecki: Kukały

○ powiat warecki: Wrociszewo, Biskupice

- ziemia warszawska

○ powiat błoński: Bąki, Biskupice, Domaniewo, Tworkowo, Żbików, Żdzary

- ziemia liwska (= powiat liwski): Grębków, Podsusze

4. Kapituła katedralna płocka

- ziemia warszawska

○ powiat warszawski: Dziekanowo (dziekan płocki), Gocław, Grochowo, Kamion, Kawęczyn

5. Kapituła kolegiaty Zwiastowania NMP i św. Mateusza w Pułtusku

- ziemia nurska

- powiat nurski: Chmielewo, Jasienica (archidiakon pułtuski), Niewskurze

○ powiat kamieniecki: Biała Dąbrowa, Długosiodło, Jaszczołty, Komorowo, Leszczydół, Obryte (prepozyt pułtuski), Popławy, Sadykierz (inaczej Pawłowo), Wola Piaseczna (osada młyńska)

6. Kapituła kolegiaty św. Jana Chrzciciela w Warszawie

- ziemia czerska

○ powiat czerski: Chabdzinek (Habdzinek), Koło (do ok. 1520 r.)

○ powiat grójecki: Broniszewo (scholastyk warszawski), Janówek

$\circ$ powiat warecki: Dębna Wola 
- ziemia warszawska

○ powiat warszawski: Długa Kościelna, Kąty, Żórawia

Odolany i Siedlec (dziekan warszawski)

○ powiat błoński: Kanie-Sulniewo (Popówek)

Giełżewo i Rokitno (archidiakon warszawski)

○ powiat tarczyński: Bystrzanowo, Duki, Tarczany

Tarczyn - miasto, Ruda, Grzędy, Kotorydz, Przypki, Wola Proboszczowa (Wola

Przypkowska) (prepozyt warszawski)

- ziemia nurska

o powiat kamieniecki: Kołodziącz (Kołodziąż), Orzełek, Raźny, Sadowne, Ugoszcza (Mrozowa Wola), Wilcze Gęby

7. Opactwo benedyktynów św. Wojciecha w Płocku

- ziemia czerska

○ powiat grójecki: Przybyszewo - miasto, Borowe, Dębowa Wola, Grabie, Jeziora Małe (Jeziórka), Osuchów, Przybyszkowice

o powiat warecki: Wyszemierzyce (Wyśmierzyce) - miasto

- ziemia nurska

o powiat kamieniecki: Zambska

8. Opactwo kanoników regularnych w Czerwińsku

- ziemia warszawska

○ powiat warszawski: Cząstkowo, Kożuszyno, Łaziska (ob. Łajski), Łomna (Łomny), Mysłogoszcz, Skrzyszewo, Trutczyno, Wieliszewo, Wieska, Wola Załubska, Załubice

○ powiat błoński: Borzęcin, Koczargi, Truskawie (inaczej: Wola Truskawska), Wojcieszyn

- ziemia nurska

○ powiat nurski: Kałęczyno, Słup, Smolewo, Zuzela

9. Prepozytura czerwińskich kanoników regularnych w Błoniu

- ziemia warszawska

- powiat warszawski: Błota, Miedzeszyn, Zawady

○ powiat błoński: Nagórna Wieś, Wawrzyszewo, Zwola (potem: Niska Wieś)

10. Klasztor norbertanek św. Marii Magdaleny w Płocku

- ziemia nurska

○ powiat kamieniecki: Barcice, Płody, Słomianka

11. Szpital św. Ducha przy kościele św. Marcina w Warszawie

- ziemia czerska

○ powiat czerski (część prawobrzeżna): Cebrowo (potem: Cegłowo), Ciska Wola (potem: Cisie), Glonkowa Wola, Kiczki, Mienia, Pełczanka, Piaseczno, Posiadały,

Rososz, Rudnik, Skwarsna Wola (Skwarne), Wagliny (Skupie)

- ziemia warszawska

○ powiat warszawski: folwark Pustoły k. Wielkiej Woli

12. Plebani kościołów parafialnych

- ziemia czerska

- powiat czerski: Linino - pleban w Czersku

- ziemia warszawska

- powiat błoński: Chroślin - pleban kościoła św. Jakuba w Rokitnie Górnym

- ziemia liwska (= powiat liwski): Wyczółki - pleban w Liwie Starym

- ziemia nurska

○ powiat kamieniecki: Sumino - pleban w Kamieńcu 


\section{Bibliografia}

\section{Źródła publikowane}

Acta ecclesiae collegiatae Varsoviensis, wyd. B. Ulanowski, Kraków 1897-1926 (Archiwum Komisji Prawniczej, 6).

Codex diplomaticus et commemorationum Masoviae generalis, wyd. J.K. Kochanowski, Warszawa 1919.

Iura Masoviae terrestria, t. 2, oprac. J. Sawicki, Warszawa 1973.

Knapiński W., Notaty do historii kościotów warszawskich, Warszawa 1949 (Materiały do Dziejów Sztuki

\section{Opracowania}

Boniecki A., Herbarz polski, t. 1-16, Warszawa 1899-1913.

Boroda K., Geografia gospodarcza Królestwa Polskiego $w X V I$ wieku, wyd. 2, Białystok 2018.

Chłapowski K., Granice i podziaty administracyjne Królestwa Polskiego i Rzeczypospolitej Obojga Narodów $w X V$-XVIII wieku, „Studia Geohistorica”, 7, 2019, s. $163-189$.

Choińska-Mika J., Mazowiecki parlamentaryzm XVIXVII w., w: Dzieje Mazowsza, t. 2: Lata 1527-1794, red. J. Tyszkiewicz, Pułtusk 2015, s. 115-165.

Dunin-Wąsowiczowa A., Podziaty administracyjne, w: Mazowsze w drugiej potowie XVI wieku, cz. 2: Komentarz $i$ indeksy, red. W. Pałucki, oprac. A. Dunin-Wąsowiczowa i in., Warszawa 1973 (Atlas historyczny Polski. Mapy szczegółowe XVI wieku, 7), s. 35-63.

Dzieje Mazowsza, t. 1, red. H. Samsonowicz, Pułtusk 2006.

Dzieje Mazowsza, t. 2: Lata 1527-1794, red. J. Tyszkiewicz, Pułtusk 2015.

Dzięgielewski J., Mazowsze w czasach ostatnich Jagiellonów, w: Mazowsze w procesach integracyjnych $i$ dezintegracyjnych $w$ Rzeczypospolitej XVI-XVII wieku. Studia i szkice, red. J. Dzięgielewski, Warszawa 2010, s. 31-53.

Ecclesia Viscoviensis. Dzieje parafii św. Idziego w Wyszkowie, red. Z. Morawski, M. Przytocka, Pułtusk 2006.

Gawlas S., Osadnictwo ziemi czerskiej w średniowieczu XII-XV w., w: Dzieje Warki 1321-1971. Studia $i$ materiaty, praca zbiorowa, red. B. Dymek i in., Warszawa 1975 , s. 20-47.

Gąsiorowski A., Starszeństwo urzędów w Polsce późnośredniowiecznej, „Roczniki Historyczne”, 35, 1969, s. 33-56.

Gieysztor A., Trzy stulecia najdawniejszego Mazowsza (potowa X-potowa XIII w.), w: Dzieje Mazowsza, t. 1, red. H. Samsonowicz, Pułtusk 2006, s. $109-160$. i Kultury Państwowy Instytut Historii Sztuki, 6), mps powielony.

Matricularum Regni Poloniae summaria, t. 4/2, wyd. T. Wierzbowski, Warszawa 1912.

Nowy kodeks dyplomatyczny Mazowsza, t. 2, wyd. I. Sułkowska-Kuraś, S. Kuraś, współpr. K. Pacuski, H. Wajs, Warszawa 1989.

Regestra thelonei aquatici Wladislaviensis saeculi XVI, wyd. S. Kutrzeba, F. Duda, Kraków 1915.

Gieysztorowa I., Charakter i wielkość osad, w: Mazowsze $w$ drugiej potowie XVI wieku, cz. 2: Komentarz $i$ indeksy, red. W. Pałucki, oprac. A. Dunin-Wąsowiczowa i in., Warszawa 1973 (Atlas historyczny Polski. Mapy szczegółowe XVI wieku, 7), s. $77-87$.

Gieysztorowa I., Mazowieckie akta skarbowe w XVXVII w., próba odtworzenia uktadu, w: Ksiega Pamiątkowa 150-lecia Archiwum Gtównego Akt Dawnych w Warszawie, Warszawa1958, s. 209-217. Gimpel D., Dzieje Wyszkowa, Warszawa 1984.

Główka D., Wieś na Mazowszu w XVI-XVI wieku, w: Dzieje Mazowsza, t. 2: Lata 1527-1794, red. J. Tyszkiewicz, Pułtusk 2015, s. 167-195.

Grabowski J., Dynastia Piastów mazowieckich. Studia nad dziejami politycznymi Mazowsza, intytulacja i genealogia książat, Kraków 2012.

Grabowski J., Dzieje Makowa w czasach Piastów Mazowieckich, w: Dzieje Makowa Mazowieckiego, t. 1, red. J. Szczepański, Maków Mazowieck-Pułtusk 2020, s. 17-85.

Grabowski J., Tytulatura na dokumentach książą mazowieckich. Forma i funkcje (wybrane zagadnienia), „Klio”, 13, 2009, s. 41-79.

Jaszczołt T., Granica pomiędzy ziemiami drohicka. i liwska w świetle protokotów komisji z 1546 roku, „Rocznik Liwski”, 6, 2012/2013, s. 13-54.

Jaszczołt T., Naptyw rycerstwa do pótnocnej części ziemi liwskiej w XV i początkach XVI wieku (parafie Korytnica i Pniewnik), „Zeszyty Korytnickie”, 4 , 2011, s. 143-169.

Jaszczołt T., Naptyw rycerstwa i szlachty na pogranicze mazowiecko-podlaskie w XV i pierwszej potowie XVI wieku (obszar dzisiejszego powiatu wysokomazowieckiego), w: Rody, rodziny Mazowsza i Podlasia. Źródta do badań genealogicznych, red. D.K. Rembiszewska, H. Krajewska, Łomża 2013, s. 159-242.

Jurek T., Biskupstwo poznańskie w wiekach średnich, Poznań 2018. 
Kartoteka Słownika historyczno-geograficznego Mazowsza w średniowieczu (https://rcin.org.pl/dlibra/ publication/8355\#structure, dostęp: 12 kwietnia 2021).

Karwasińska J., Wybór pism. Kujawy i Mazowsze, Warszawa 1997.

Kawałkowa E., Osadnictwo pradziejowe i średniowieczne $w$ dolinie dolnej Narwi, w: Narew w dziejach i wspótczesności Mazowsza i Podlasia, red. A. Dobroński, W. Grębecka, Łomża 2004, s. 149-172.

Kowalczyk E., Osadnictwo ziemi liwskiej do potowy $X I V w . w$ świetle źródet pisanych, w: Stowiańszczyzna $w$ Europie średniowiecznej, t. 2, red. Z. Kurnatowska, Wrocław 1996, s. 193-197.

Kowalczyk-Heyman E., Najstarsze nazwy miejscowe ziemi liwskiej, „Rocznik Liwski”, 7, 2014, s. 9-16.

Królik L., Kapituła kolegiacka $w$ Warszawie do końca XVIII wieku, Warszawa 1990.

Mazowsze w drugiej potowie XVI wieku, cz. 1-2, red. W. Pałucki, oprac. A. Dunin-Wąsowiczowa i in., Warszawa 1973 (Atlas historyczny Polski. Mapy szczegółowe XVI wieku, 7).

Nowik A.M., Dzieje Cegtowa do 1795 roku, w: Na cegle pisane. Historia miasteczka Cegtów, red. M. Śluzek, Cegłów 2021, s. 1-39.

Pacuski K., Dzieje osady i parafii [Wyszków] w średniowieczu, w: Ecclesia Viscoviensis. Dzieje parafii sw. Idziego w Wyszkowie, red. Z. Morawski, M. Przytocka, Pułtusk 2006, s. 29-47.

Pacuski K., Elita wtadzy ziemi liwskiej w XVw., „Rocznik Liwski”, 1, 2005/2006, s. 73-93.

Pacuski K., Możnowtadztwo i rycerstwo ziemi gostynińskiej w XIV i XV wieku. Studium z dziejów osadnictwa $i$ elity wtadzy na Mazowszu średniowiecznym, Warszawa 2009.

Pacuski K., O rodzie Radwanów-Wierzbowów na Mazowszu średniowiecznym. Potomkowie Gotarda kasztelana wiskiego, w: Stużew i jego kościót, red. A. Sołtan-Lipska, Warszawa 2013, s. 35-67.

Pacuski K., Otoczenie księcia warszawskiego w kwietniu 1313 r., w: Ecclesia - regnum - fontes. Studia $z$ dziejów średniowiecza. Prace ofiarowane Profesor Marii Koczerskiej, red. S. Gawlas i in., Warszawa 2014, s. 206-216.

Pacuski K., Prażmowski Wawrzyniec, w: Polski stownik biograficzny, t. 28, Wrocław 1984-1985, s. 391-393.

Pacuski K., Uposażenie klasztoru czerwińskiego w XIIXVI wieku, w: Dzieje klasztoru w Czerwińsku, red. E. Olbromski, Lublin 1997, s. 15-24.

Pacuski K., Wschodnia granica Mazowsza $w$ średniowieczu w świetle danych historycznych $(X-X V w$.), w: Początki chrześcijaństwa na pograniczu mazowiecko-ruskim w świetle wyników badań wybranych cmentarzysk, red. A. Buko, Warszawa 2019, s. 15-32.

Pacuski K., Wspótpracownicy książąt mazowieckich $w$ ziemi warszawskiej $w$ XIV wieku, w: Poczatki
Warszawy. Spojrzenie po 700 latach, red. H. Rutkowski, Warszawa 2015, s. 53-72.

Pałucki W., Przynależność wtasnościowa osad, w: Mazowsze $w$ drugiej potowie XVI wieku, cz. 2: Komentarz $i$ indeksy, red. W. Pałucki, oprac. A. Dunin-Wasowiczowa i in., Warszawa 1973 (Atlas historyczny Polski. Mapy szczegółowe XVI wieku, 7), s. 88-102.

Pazyra S., Geneza i rozwój miast mazowieckich, Warszawa 1959.

Piber-Zbieranowska M., „Księżna mazowiecka Anna Radziwiłłówna i jej regencja na Mazowszu (15031518)", Warszawa 2019, mps pracy doktorskiej w Bibliotece IH PAN w Warszawie.

Piber-Zbieranowska M., Udziat szlachty ziemi liwskiej $w$ zarzadzie księstwem mazowieckim $w$ latach 1503-1526. Wybrane przyktady, „Rocznik Liwski”, 8, 2015, s. 133-147.

Piber-Zbieranowska M., Uwagi nad początkami powiatu garwolinskiego w ziemi czerskiej, w: Fines testis temporum. Studia ofiarowane Profesor Elżbiecie Kowalczyk-Heyman w pięćdziesięciolecie pracy naukowej, red. M. Dzik, G. Śnieżko, Rzeszów 2017, s. 9-106.

Russocki S., Formy wtadania ziemia w prawie ziemskim Mazowsza. Koniec XIV-potowa XVI wieku, Warszawa 1962.

Russocki S., Nadania ziemi „ad servitia communia" a obowiązek stużby wojskowej na Mazowszu wXV wieku, w: Miscellanea iuridica ztożone w darze Karolowi Koranyiemu w czterdziestolecie pracy naukowej, red. K. Bukowska, Warszawa 1961, s. 111-119.

Russocki S., Pacuski K., Ustrój polityczny i prawo, w: Dzieje Mazowsza, t. 1, red. H. Samsonowicz, Pułtusk 2006, s. 395-445.

Rutkowski H., Lokalizacja miejscowości, w: Mazowsze $w$ drugiej potowie XVI wieku, cz. 2: Komentarz $i$ indeksy, red. W. Pałucki, oprac. A. Dunin-Wąsowiczowa i in., Warszawa 1973 (Atlas historyczny Polski. Mapy szczegółowe XVI wieku, 7), s. 64-76.

Samsonowicz H., Supruniuk A., Dzieje polityczne (potowa XIV-początek XVI w.), w: Dzieje Mazowsza, t. 1, red. H. Samsonowicz, Pułtusk 2006, s. 257-338.

Senkowski J., Skarbowość Mazowsza od końca XIV wieku do 1526 roku, Warszawa 1965.

Stownik historyczno-geograficzny ziemi liwskiej w średniowieczu, oprac. M. Piber-Zbieranowska, A. Salina, przy współpr. E. Kowalczyk-Heyman, red. T. Jurek, Warszawa 2017.

Stownik historyczno-geograficzny ziemi warszawskiej $w$ średniowieczu, oprac. A. Wolff, K. Pacuski, przyg. do druku M. Piber-Zbieranowska, A. Salina, red. T. Jurek, Warszawa 2013.

Sobol B., Sejm i sejmiki ziemskie na Mazowszu książecym, Warszawa 1968.

„Spis urzędników ziemskich mazowieckich XIIIXV wieku", oprac. K. Pacuski, mps w Zakładzie 
Słownika Historyczno-Geograficznego Ziem Polskich w Średniowieczu IH PAN w Poznaniu.

Stawski M., Opactwo czerwińskie w średniowieczu, Warszawa 2007.

Szczepański J., Ziemie Mazowsza w okresie insurekcji 1794 roku, w: Dzieje Mazowsza, t. 2: Lata 1527 1794, red. J. Tyszkiewicz, Pułtusk 2015, s. 601-628.

Warężak J., Rozwój uposażenia arcybiskupstwa gnieźnieńskiego w średniowieczu, Lwów 1929.

Węcowski P., Mazowsze w Koronie. Propaganda i legitymizacja wtadzy Kazimierza Jagiellończyka na Mazowszu, Kraków 2004.

Wilska M., Mazowieckie środowisko dworskie Janusza Starszego. Studium spoteczne, Warszawa 2012.
Wiśniewski J., Początek i rozwój nowego osadnictwa $w$ ziemi tomżyńskiej $w$ końcu XIV i $w X V$ wieku, „Studia Łomżyńskie”, 1, 1989, s. 19-107.

Wittyg W., Nieznana szlachta polska i jej herby, Kraków 1908.

Wolff A., Starszeństwo urzędów. Metoda ustalania na przyktadzie hierarchii Mazowsza udzielnego, Warszawa 1928.

Wolff A., Studia nad urzędnikami mazowieckimi 1370-1526, Wrocław-Warszawa-Kraków 1962.

Wolff A., Ziemia tomżyńska w średniowieczu, Łomża 1988.

Żaboklicka A., Zmiany w strukturze drobnej wtasnosici szlacheckiej $X V-X V I$ w. na przyktadzie ziemi liwskiej, „Przegląd Historyczny”, 49 (2), 1958, s. $250-260$.

\section{The Duchy of Mazovia on the eve of incorporation. Characteristics of the territory c. 1526 (its southern part)}

\section{Summary}

Just before its incorporation into the Kingdom of Poland in 1526, the territory of the Duchy of Mazovia covered a total of just over 23,000 square kilometres. It included ten lands, ranked according to their contemporary political importance as follows: the Land of Czersk, Wizna, Warsaw, Wyszogród, Zakroczym, Ciechanów, Liw, Łomża, Nur, and Maków-Różan. The lands were divided into counties ( 24 in total). The article describes four southern lands: of Czersk, Warsaw, Liw, and Nur. The first two made the political core of the last Piasts' rule (the ruling elite originated here), while the latter two were separated from those in the fifteenth century. The remaining six lands are presented in the second part of the text, whose publication is planned for later. The Czersk and Warsaw Lands belonged to the areas of the oldest settlements (continuously since the twelfth century). These were the most urbanised lands of the principality (20 towns, including 14 on the left bank of the Vistula). The largest concentrations of ducal property in Mazovia were located there. On the other hand, Church property was relatively small and dispersed: 2 towns and 48 villages (Czersk Land); 1 town and 53 villages (Warsaw Land). In the Czersk Land, the most extensive estates were held by the bishopric of Poznań, the Warsaw Hospital of the Holy Spirit and the Benedictine abbey in Płock; in Warsaw Land - by the abbey of Canons Regular at Czerwińsk and the chapter of St John the Baptist collegiate church in Warsaw. Slightly different was the structure of the villages belonging to the nobility. In the Czersk Land, the middle nobility dominated, and only 13 per cent of the total number of the noble villages were in the hands of the petty nobility with no peasants; in the Warsaw Land, it was 30.4 per cent. The one-county Liw Land separated from the Czersk Land after 1471. It did not have a developed urban network; until 1526, there were two towns (in fact, one double town: Old and New Liw) which, together with several villages, were the duke's property. Church estates were very small here (three villages). The nobility owned over 90 per cent of all villages in this area, with over a half belonged to the peasant-less nobility. In the Land of Nur, settlements of large size but sparsely distributed prevailed. The density of the urban network was one of the lowest in the Duchy. The ownership structure in Nur Land varied greatly depending on the county. In the counties of Nur and Ostrów, the duke's ownership was very small, in Kamieniec county, the dukes owned the large landed estates with their centre at Kamieniec. The lands on the Brok River and its right tributaries (Nur county), as well as vast areas north of the Bug River (Kamieniec county), belonged to the Church (mainly to the 
bishopric of Płock and the Pułtusk chapter). In the administrative county of Nur, the villages of the petty nobility significantly dominated, as they owned 90.2 per cent of the noble estates. These villages were also very fragmented $(1 / 4$ had ten or more owners). On the other hand, in counties of Ostrów and Kamieniec, the majority of villages were inhabited by peasants (over 70 per cent of the total), and villages of poor nobility were usually divided into two to six sections. In the analysed period, there was no noble family from the lands of Liw and Nur, which could be counted among the Mazovian elite of mighty and wealthy.

dr Marta Piber-Zbieranowska - pracownik naukowy w Instytucie Historii im. Tadeusza Manteuffla Polskiej Akademii Nauk, w latach 1998-2012 w Zakładzie Atlasu Historycznego, od 2012 r. w Zakładzie Słownika Historyczno-Geograficznego Ziem Polskich w Średniowieczu. Specjalizuje się w dziejach średniowiecznego i wczesnonowożytnego Mazowsza oraz geografii historycznej Polski i historii kartografii. Jej zainteresowania badawcze koncentrują się również wokół kobiecych rządów regencyjnych w średniowiecznej Polsce i politycznej roli kobiet w tym okresie

(mpiber@ihpan.edu.pl)

Marta Piber-Zbieranowska, PhD - researcher at the Tadeusz Manteuffel Institute of History of the Polish Academy of Sciences, in 1998-2012 employee at the Department of the Historical Atlas, since 2012 in the Department of the Historical-Geographical Dictionary of the Polish Lands in the Middle Ages. She specialises in the history of settlement of late-medieval and early modern Mazovia, also in the historical geography of Poland and in the history of cartography. She is especially interested also in the female regent's government in the Polish land in the Middle Ages and in the political role of women in this period (mpiber@ihpan.edu.pl) 